\title{
Essay
}

\section{George Stigler on His Head: The Consequences of Restrictions on Competition in (Bank) Regulation}

\author{
Prasad Krishnamurthy ${ }^{\dagger}$
}

Bank regulation used to be riddled with price, product, entry, and location restrictions. Such restrictions were intended to prevent the recurrence of crises, such as those of the 1930s and 1940s. Over time, however, regulatory acquiescence to technological and institutional innovation undermined their ability to limit competition. An intellectual turn toward valorizing competition also hastened their demise. George Stigler, in particular, provided a trenchant critique of all such regulation as the product of pure rent seeking by private industry.

This Article revisits the role of such restrictions on competition in banking. On the one hand, the public choice account of these restrictions as the outcome of private rent seeking is essentially true. On the other hand, their unintended historical result was to limit banks' risk-taking incentives and to coopt banks into preventing regulatory arbitrage. Viewed from this perspective, these restrictions provide an important legal, political, and economic (LPE) model for how limits on competition could usefully complement current bank regulation. This model is one in which, to some extent, regulation facilitates rather than frustrates cartel formation in order to maintain a more stable equilibrium.

Introduction.

$\dagger$ Professor of Law, U.C. Berkeley Law School, 685 Simon Hall, Berkeley, CA, prasad@law.berkeley.edu. The author thanks George Akerlof, Ken Ayotte, Ian Ayres, Michael Barr, Robert Bartlett, Ryan Bubb, Omri Ben-Shahar, Robert Cooter, Jim Cox, Brad DeLong, Dhammika Dharmapala, Dan Farber, Melanie Fein, Stavros Gadinis, Mark Gergen, Jeff Gordon, Joseph Grundfest, Daniel Hemel, Todd Henderson, Dan Ho, Parham Holakouee, Kate Judge, Mike Klausner, Saul Levmore, Anup Malani, Paul Mahoney, Geoffrey Miller, Frank Partnoy, Mark Perlow, Randy Picker, Eric Posner, the late Moishe Postone, N.R. Rao, K. Sabeel Rahman, Adriano Rampini, Morgan Ricks, Daria Roithmayr, Daniel Schwarcz, Peter Schuck, Steven Davidoff Solomon, Holger Spamann, Emmanuel Saez, David Sraer, Eric Talley, Glen Weyl, Yesha Yadav, David Zaring, participants at Vanderbilt Law School's conference on Rethinking the Public Utility, participants at seminars at Columbia, San Diego, and Yale Law School, students in Berkeley's Financial Regulation course, and the interwebs for helpful conversations. 


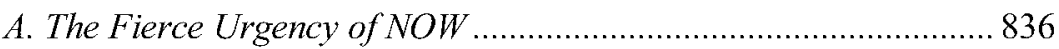

B. Public Choice ......................................................................... 841

C. Rent Dissipation ............................................................. 845

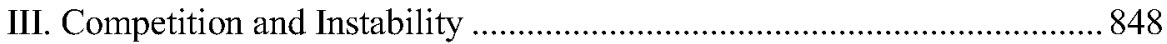

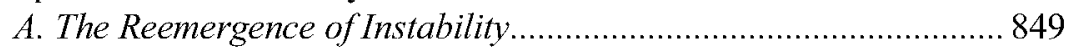

1. Rethinking Competition...................................................... 849

2. A History of the Present......................................................... 852

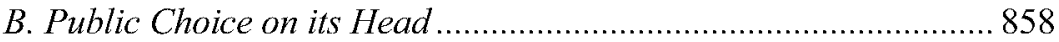

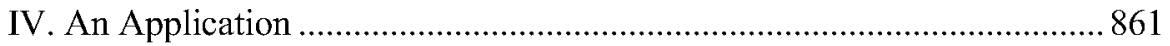

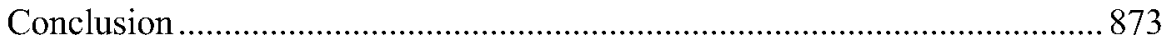

\section{Introduction}

The state has one basic resource which in pure principle is not shared with even the mightiest of its citizens; the power to coerce. . . . These powers provide the possibilities for the utilization of the state by an industry to increase its profitability. ${ }^{1}$ - George Stigler (1971)

Many of the key events in the recent financial crisis resembled an oldfashioned bank run. ${ }^{2}$ Investors in the short-term debt of major financial institutions feared their large exposures to bad mortgage loans. As a result, they refused to roll over the debt and took refuge in the safety of government bonds. ${ }^{3}$ Even fundamentally solvent institutions were threatened by this loss of short term funding or liquidity. ${ }^{4}$ The end result was a large-scale contraction in the supply of credit - a "credit crunch" - that helped to cause and prolong a deep economic recession. ${ }^{5}$ The immediate economic consequences of these events were dire, and their political and legal consequences are still unfolding.

These events would seem very familiar to a nineteenth-century observer of U.S. banking. Major banking panics occurred at least once per decade throughout most of the nineteenth and early twentieth centuries, and many were preceded by widespread real estate speculation. ${ }^{6}$ These recurring panics commanded

1. George J. Stigler, The Theory of Economic Regulation, 2 BELL J. ECON. \& MGMT. SCI. 3, 4 (1971).

2. See Gary Gorton, SLAPPED By the Invisible Hand: The Panic OF 2007 (2010) (arguing that the panic of 2007 should be viewed as a banking panic)

3. See Bryan Noeth \& Rajdeep Sengupta, Flight to Safety and U.S. Treasury Securities, REGIONAL ECONOMIST 18 (2010), http:/www.stlouisfed.org/ /media/Files/PDFs/publications /pubps_assets/pdf/re/2010/c/treasury_securities.pdf [http:/perma.cc/2KBK-2Y32]

4. Markus K. Brunnermeier, Deciphering the Liquidity and Credit Crunch 2007-2008, 23 J. ECON. PERSP. 90 (2009).

5. Id. (describing the dynamics of a credit crunch).

6. Charles Calomiris \& Gary Gorton, The Origins of Banking Panics: Models, Facts, and Regulation, in FINANCIAL MARKETS AND FINANCIAL CRISES 109 (R. Glenn Hubbard ed., 1991). From the War of 1812 to the eve of World War I in 1914, the United States experienced at least ten episodes involving large-scale suspensions of payment by banks to their depositors. For a comprehensive 
popular attention and triggered a number of legislative responses. The National Bank Act of 1864 created a national currency, a national banking system, and a national regulator (the Office of the Comptroller of the Currency) to oversee the system. ${ }^{7}$ The Federal Reserve Act of 1914 created a central bank with the ability to lend to member banks. ${ }^{8}$ Many states set up their own deposit insurance schemes. ${ }^{9}$ But these efforts were not successful in limiting the incidence of panics, and the 1930 s witnessed the greatest financial crisis in the history of the United States.

Remarkably, in the decades after the Great Depression there were no largescale banking crises in the United States. ${ }^{10}$ This period coincided with the creation of a distinct legal and regulatory system to govern banking. The New Deal system was created through a flurry of Depression-era legislation. It was characterized by a few key features: (1) access to central bank lending, (2) deposit insurance, (3) examination and regulation of bank assets and liabilities, (4) price controls on deposit interest rates, (5) product restrictions that separated commercial and investment banking, and (6) entry and location restrictions on bank expansion. Taken together, these provisions reflected a view that bank competition, if left unregulated, would lead to socially unacceptable levels of risk taking and crises.

History has not been equally kind to the components of this system. Central bank lending, deposit insurance, and supervision continue to play an essential role in federal bank regulation, but the price, product, entry, and location restrictions that were a hallmark of New Deal bank regulation are largely a relic of the past. The Deposit Institution Deregulation and Monetary Control Act of 1980 phased out interest-rate ceilings on all bank accounts other than demand deposits, ${ }^{11}$ the Riegle-Neal Interstate Banking and Branching Efficiency Act of 1994 permitted nation-wide branching, ${ }^{12}$ and the Financial Services Modernization (Gramm-Leach-Bliley) Act of 1999 revised sections of the GlassSteagall Act to allow banks, broker-dealers, and insurance companies to affiliate with one another through a financial holding company structure. ${ }^{13}$

In each of these instances, the act of deregulation was more a consequence of changes in banking markets than a cause of it. Long before the recent financial

historical account of the role that law and legal institutions have played in financial crashes, see ERIK GERDING, LAW, BUBBLES, AND FINANCIAL REGULATION (2014).

7. National Bank Act, ch. 106, $§ 7,13$ Stat. 99, 101 (1864) (codified as amended in scattered sections of 12 U.S.C.).

8. Federal Reserve Act, Pub. L. No. 63-43, 38 Stat. 251 (codified as amended at 12 U.S.C. $\S \S 221-522(2018))$

9. Charles Calomiris, Is Deposit Insurance Necessary? A Historical Perspective, $50 \mathrm{~J}$. ECON. HIST. 283 (1990).

10. See GORTON, supra note 2 at 14 .

11. Pub. L. No. 96-221, 94 Stat. 132 (codified in scattered sections of 12 \& 15 U.S.C.).

U.S.C.).

12. Pub. L. No. 103-328, 108 Stat. 2338 (1994) (codified in scattered sections 12

13. Pub. L. No 106-102, 113 Stat. 1338 (1999) (codified as amended in scattered sections of 12 U.S.C. and 15 U.S.C.). 
crisis and the concerned discussions of the "shadow banking" system that followed, informed observers were aware that the forces of competition were moving banking activity outside of deposit-taking institutions. ${ }^{14}$ These developments rendered the price, product, entry, and location restrictions on banks increasingly obsolete. ${ }^{15}$ Money market funds and Eurodollar accounts competed with bank deposits, non-bank lenders were free to operate nationally, and capital markets provided an increasing share of the debt financing that had been the historical preserve of commercial banks. ${ }^{16}$ As a result of these developments, many institutional aspects of the recent crisis would have been quite unfamiliar to architects of the New Deal system.

This reappearance of banking panics in a new institutional guise poses a difficult set of questions for bank regulation. Before the crisis, it was known that institutions such as broker-dealers, special purpose securitization vehicles, and money market funds were part of the broader banking system. ${ }^{17}$ It was also known that the short-term debt issued by such institutions-repurchase agreements, asset-backed commercial paper, and money market shares - were important substitutes for bank deposits. ${ }^{18}$ But for almost all observers, the crisis revealed that these markets are much more vulnerable to banking panics than was previously thought and that such panics can spill over in a number of ways to the more traditional banking system.

It is therefore tempting to look back on the "quiet period" that followed the Great Depression and the regulatory system that accompanied it - for answers. ${ }^{19}$ If bank regulation played an important role in maintaining this stability, it follows that deregulation could have undermined it. This temptation is best illustrated in calls to reintroduce the separation of commercial and investment banking associated with the Glass-Steagall Act. ${ }^{20}$ Yet, this Glass-

14. See Jonathan R. Macey \& Geoffrey P. Miller, Nondeposit Deposits and the Future of Bank Regulation, 91 MICH. L. REV. 237 (1992) (discussing the growth of deposit substitutes such as repurchase agreements, money market funds, and Eurodollar accounts).

VA. L. REV. 304 (1987)

15. Daniel R. Fischel et al., The Regulation of Banks and Bank Holding Companies, 73

16. Id.

17. See Gary Gorton, Money Market Funds and Finance Companies: Are They the Banks of the Future?, in STRUCTURAL CHANGE IN BANKING (Michael Klausner \& Lawrence White eds., 1993) (arguing that money market funds and finance companies perform important banking functions); Gary Gorton \& Nicholas Souleles, Special Purpose Vehicles and Securitization (Nat'l Bureau of Econ. Research, Working Paper No. 11190, 2005) (arguing that special purpose vehicles for securitization serve important banking functions).

18. Macey \& Miller, supra note 14 at 237.

19. For a comprehensive account of the definition and evolution of bank holding companies from this period to the present, see Saule T. Omarova \& Margaret E. Tahyar, That Which We Call a Bank: Revisiting the History of Bank Holding Company Regulation in the United States, 31 REV. BANKING \& FIN. L. 113-198 (2011).

20. A small, yet prominent group of politicians from across the political spectrumincluding Senators Elizabeth Warren, Bernie Sanders, and John McCain have voiced support for such an effort and have even introduced a bill to this purpose. See 21 st Century Glass-Steagall Act, S. 881, 115th Cong. (2017). 
Steagall revivalism has attracted little enthusiasm in the academic and policy community. ${ }^{21}$

In fact, the broader thesis that financial deregulation was responsible for the financial crisis has also faced notable criticism. In a comprehensive, recent account, Paul Mahoney argues persuasively that there is no simple and direct relationship between recent statutory changes and the specific activities that led to the financial crisis. ${ }^{22}$ The financial institutions that were responsible for the crisis were broadly authorized to carry out all of these activities for decades preceding it. Mahoney argues further that the quiet period in banking from the Great Depression to the 1970 s and its subsequent unraveling had little to do with regulation or deregulation. Mahoney instead attributes this pattern of calm followed by turbulence to broader economic forces that were channeled through interest rates. ${ }^{23}$

Does this imply that there is nothing to be learned from New Deal regulation and its role in the quiet period of U.S. banking history? In this Article, I suggest that such a conclusion would be premature. The history of price, product, entry and location restrictions, of which the Glass-Steagall Act was but one part, provides important lessons for contemporary regulation. Perhaps paradoxically, these lessons are best seen by starting with George Stigler's observation, "as a rule, regulation is acquired by the industry and is designed and operated primarily for its benefit." 24 The competitive restrictions in New Deal bank regulation can be described as a textbook illustration of industry rent seeking and capture and, by implication, Stigler's "public choice" view of regulation. ${ }^{25}$

I suggest that, in addition, the rents created through these restrictions also helped to solve two problems that are central to contemporary bank regulation. First, they lowered the incentives of banks to take excessive risk and, crucially, did so without requiring regulators to precisely monitor risk-taking activities. ${ }^{26}$

21. Its critics have raised a number of important objections. The financial crisis arose in a very traditional area of banking - mortgage lending — and its effects were spread across many types of financial institutions.

22. Paul G. Mahoney, Deregulation and the Subprime Crisis, VA. L. REV. (forthcoming 2018), http:/papers.ssrn.com/sol3/papers.cfm?abstract id $=2957801 \quad$ [http:/perma.cc/7YG9-8SBK]. Mahoney analyzes the Gramm-Leach Bliley Act of 1999, which repealed parts of the Glass-Steagall Act and the Commodities Futures Modernization Act of 2000, which largely blessed the set of existing practices concerning over-the-counter derivatives.

23. Id. at 5 .

24. Stigler, supra note 1, at 3; see also Richard A. Posner, Theories of Economic Regulation, 5 BELL J. ECON. \& MGMT. SCI. 335 (1974) (discussing the power and limitations of this view of regulation); Sam Peltzman, Toward a More General Theory of Regulation, 19 J.L. \& ECON. 211 (1976) (discussing the same).

25. See Charles Calomiris, The Political Lessons of Depression-Era Banking Reform, 26 OXFORD REV. ECON. POL'Y 540 (2010); see also Jonathan R. Macey, Special Interest Groups Legislation and the Judicial Function: The Dilemma of Glass-Steagall, 33 EMORY L.J. 1 (1984) (applying these insights to analyze the Depression era legislation and its legal interpretation).

26. The view that rents can lower bank risk taking, while far from universally accepted, is consistent with a body of theoretical and empirical research on the relationship between competition 
Second, they created incentives for banks to prevent banking activity from moving outside the regulated banking system. I summarize how the legal, political and economic (LPE) architecture of this system created the incentives, monitoring capability, and enforcement authority to achieve these ends. More generally, I explain how the theory of oligopoly, a mainstay of public choice critiques of regulation, can sometimes help to explain its effectiveness. ${ }^{27}$

I conclude by outlining one model, among many possible ones, that seeks to apply these past insights to the present. In this model, prudential regulation operates so as to limit the amount of panic-prone debt that could be issued by bank holding companies. Regulation simultaneously extends to non-bank financial companies so as to even further limit their issuance of such debt or its close substitutes. This model creates a framework of privileges and prohibitions that limits the aggregate quantity of such debt and concentrates it in the regulated banking sector. ${ }^{28}$ The effect is to raise the price of panic-prone debt and lower its yield, creating a rent or funding advantage for regulated banks. The use of regulation to affect prices in this market is no different in kind than Federal Reserve policy to affect short-term interest rates in the pursuit of monetary policy. ${ }^{29}$ However, it has the additional effect of limiting bank incentives for risk taking to preserve a utility model of safe returns, while enlisting banks to protect this privilege by aiding regulators in their enforcement against nonbanks.

The rest of Article is organized as follows. Part I explains what I call the orthodox view of bank regulation and how it gives rise to problems of risk

and stability in banking. See, e.g., Franklin Allen \& Douglas Gale, Competition and Financial Stability, 36 J. MONEY, CREDIT, \& BANKING 453 (2004); Elena Carletti, Competition and Regulation in Banking, in HANDBOOK OF FINANCIAL INTERMEDIATION AND BANKING 449 (Anjan V. Thakor \& Arnoud W.A. Boot eds., 2008); XAVIER VIVES, COMPETITION AND STABILITY IN BANKING: THE ROLE OF REGULATION AND COMPETITION POLICY (2016) (explaining the economic theory and evidence for and against this view).

27. For a different account of how to think about the role of state power in financial regulation, see Robert C. Hockett \& Saule T. Omarova, The Finance Franchise, 102 CORNELL L. REV. 1143 (2017). In contrast to Hockett and Omarova, the notion of rent I employ does not inevitably follow from the grant of a government franchise. In particular, an open-franchise policy in a competitive setting may not generate rents for franchisees.

28. For another approach to how banking regulation could utilize privileges and prohibitions, see MORGAN RICKS, THE MONEY PROBLEM: RETHINKING FINANCIAL REGULATION (2016). In contrast to Ricks, the approach I describe requires neither explicit government insurance of all shortterm debt (money-like claims) nor an absolute prohibition on all such instruments outside the regulated banking sector. For an insightful review, see Kathryn Judge, The Importance of Money, 130 HARV. L. REV. 1148 (2017). For an illuminating account of how the legal organization of monetary and currency regimes are central to financial crises in small, open economies, see Horacio Spector, Don't Cry for Me Argentina: Economic Crises and the Restructuring of Financial Property, 14 FORDHAM J. CORP. \& FIN. L. 771 (2009).

29. Former Federal Reserve Govemor Jeremy Stein has also outlined an approach to monetary policy that would address financial stability. According to Stein, monetary policy should be less accommodative when financial sector leverage is high. See Jeremy C. Stein, Incorporating Financial Stability Considerations into a Monetary Policy Framework, Address at the International Forum on Financial Stability (Mar. 21, 2014); Jeremy C. Stein, Monetary Policy as Financial Stability Regulation (Nat'l Bureau of Econ. Research Working Paper No. 16883, 2011). In the model that I outline, monetary policy would be more accommodative, relative to Stein's view, because existing regulation would constrain aggregate financial sector leverage. 
monitoring and regulatory arbitrage. Part II describes how statutory, regulatory, and enforcement powers were historically deployed to create rents by suppressing competition between banks and documents how market forces, aided by regulatory acquiescence, undermined these rents over time. Part III suggests that this anticompetitive LPE architecture also played an important role in limiting bank risk taking and preventing regulatory arbitrage. Part IV outlines a model through which these insights can inform contemporary bank regulation.

\section{Regulation: The Orthodox View}

Before turning to the past, it is useful to first reacquaint ourselves with the present. At the risk of simplifying, contemporary U.S. bank regulation is organized around three institutional pillars: (1) central bank lending, (2) deposit insurance, (3) and prudential regulation. Each is an imposing legal and administrative edifice that has evolved considerably over time. The Federal Reserve System was created by the Federal Reserve Act of $1913,{ }^{30}$ while the FDIC was created and then made a permanent agency, respectively, by the Banking Acts of $1933^{31}$ and $1935 .{ }^{32}$ Recounting the history of theory and practice for any one of these pillars, let alone all three, would require a treatise. Thankfully, such a treatise is not necessary. It is an achievement of contemporary banking regulation that a coherent conceptual framework ties these pillars together in a relatively simple way. In an even rarer correspondence between history and logic, the sequence of adoption of these policies and their subsequent development is also consistent, more or less, with this conceptual framework. This Part describes how basic insights from information economics tie together or, in the jargon of economics, render rational most of contemporary bank regulation. These insights apply with equal force to the Basel Accords, ${ }^{33}$ which have organized bank regulation across the G20 nations for the past three decades, as well as the Dodd-Frank Act of $2010,{ }^{34}$ which takes familiar principles in bank regulation and extends them to a broader set of institutions and markets.

Whatever conceptual coherence may exist in contemporary banking regulation, there is still little reason to think we have arrived at the end of history. The regulatory response to the greatest financial crisis and recession in the

30. Ch. 6, 38 Stat. 251 (1913) (codified as amended at 12 U.S.C. $\S 226$ )

31. Pub. L. No. 73-66, 48 Stat. 162 (1933) (codified as amended at 12 U.S.C. $\S 227$ )

32. Ch. 614, 49 Stat. 684 (1935) (codified as amended at 12 U.S.C. $\$ 228$ ).

33. Basel Committee on Banking Supervision, International Convergence of Capital Measurement and Capital Standards, BANK FOR INT'L SETTLEMENTS (1988), http://www.bis.org/publ bcbsc111.pdf [http:/perma.cc/WDS7-9FYG] [hereinafter Basel I]; Basel Committee on Banking Supervision, International Convergence of Capital Measurement and Capital Standards: A Revised Framework, BANK FOR INT'L SETTLEMENTS (2005), http:/www.bis.org/pub1/bcbs128.pdf [http:// perma.cc/C6HR-CPMZ] [hereinafter Basel II]; Basel Committee on Banking Supervision, Basel III: Finalising Post-Crisis Reforms, BANK FOR INT'L SETTLEMENTS (2017), http://www.bis.org/bcbs/publ /d424.pdf [http://perma.cc/8QNK-X9EM].

34. Pub. L. No. 111-203, 124 Stat. 1376 (2010) (codified in scattered sections of the

U.S. Code). 
United States, at least with respect to banking, largely doubled down on an existing set of practices. ${ }^{35}$ Rather than instilling confidence, this recapitulation should give rise to suspicion - whether among scholars, policymakers, or the general public about its likely success. As explained in this Part, the conceptual weaknesses of existing regulation are well understood, and these weaknesses played a central role in the recent crisis. While ready-to-hand solutions do not exist, there is no cause for intellectual complacency or self-satisfaction in the field of banking or financial regulation. At least to some degree, both dissatisfaction with the current orthodoxy and search for viable alternatives are necessary for a healthy debate.

This brings us to the orthodoxy. According to standard economic theory, if banking activity requires regulation this phenomenon must be the result of a particular market failure. ${ }^{36}$ Banking panics are the most fundamental market failure that banking regulation seeks to address. ${ }^{37}$ Bank regulation therefore requires a conceptual framework that can both explain banking panics and assess the costs and benefits of attempts to mitigate their effects. The potential for banking panics arises from the very nature of banking activity. Banking institutions, defined broadly, engage in substantial levels of credit, liquidity, and maturity transformation. ${ }^{38}$ They finance risky, illiquid, and long-term assets by issuing safe, liquid, and short-term liabilities. This makes the banking system subject to instability from coordination failures - that is, excessive withdrawals of funding to the system by depositors or other investors. ${ }^{39}$ Such withdrawals can be triggered by the revelation of unexpected risks or losses in the banking system. ${ }^{40}$ By disrupting both the supply and demand for credit, banking panics can result in inefficiently large and prolonged contractions of economic activity. ${ }^{41}$

35. For example, it is fair to call the changes that took place from Basel II to Basel III as ones largely of degree rather than kind. See Anat Admati, The Missed Opportunity and Challenge of Capital Regulation, 235 NAT'L INST. ECON. REV. 4 (2016) (criticizing the Basel approach).

36. See Mathias Dewatripont \& Jean Tirole, The Prudential Regulation of BANKS (1994) (explaining bank regulation as a response to different market failures).

37. Calomiris \& Gorton, supra note 6.

38. All theoretical descriptions of banking are historically contingent. The features described here are characteristic of banking in the twentieth century. Maturity transformation was not as important a feature of banking in the nineteenth century. MICHAEL S. BARR ET AL., FINANCIAL REGULATION: LAW AND POLICY 184 (2016). Nineteenth century banks held predominantly short-term assets. Yet the problems of credit and liquidity transformation were sufficient enough to feature regular banking panics.

39. See Douglas W. Diamond \& Philip H. Dybvig, Bank Runs, Deposit Insurance, and Liquidity, 91 J. POL. ECON. 401 (1983) (providing a canonical account of bank runs.)

40. V.V. Chari \& Ravi Jagannathan, Banking Panics, Information, and Rational Expectations Equilibrium, 43 J. FIN. 749 (1988) (providing a canonical account of bank runs based on depositor inferences about bank health but without imposing the constraint that banks honor withdrawals on first-come, first-served basis).

41. Ben S. Bernanke, Nonmonetary Effects of the Financial Crisis in the Propagation of the Great Depression, 73 AM. ECON. REV. 257 (1983). 
Banking activity therefore creates a textbook example of an externality. Individual banks and investors in banks do not internalize the risks to the financial system - in the form of banking panies - from the issuance of bank debt. ${ }^{42}$ Left to their own devices, markets are likely to produce too much bank debt and to be too unstable from a social point of view. Consistent with this observation, banking panics were commonplace throughout the nineteenth century when there was little regulatory oversight of banking and liberal conditions of entry. ${ }^{43}$

Creating a central bank with the ability to serve as a lender of last resort can help mitigate such panics. In a panic, most banks are unable to pay depositors not because they are insolvent but because they are illiquid. They lack the ability to raise funds by selling assets or borrowing against them without incurring large losses in the process. A central bank should, according to Walter Baghot's dictum, lend freely to banks against good collateral in order to quell a panic. ${ }^{44}$ Consistent with this dictum, the Federal Reserve Act of 1913 created a central banking system with the aim of preventing the recurrence of banking panics. ${ }^{45}$ Member banks were granted the ability to borrow through the Federal Reserve system. Funds obtained in this way were held in the form of reserves with a regional Federal Reserve Bank. The intended effect of central bank reserves and access to lending was to provide additional confidence to bank depositors. However, the limited ability of the Federal Reserve to stabilize the banking system in the 1930s suggested that other policy tools were required to supplement this role of the central bank.

A more direct way of preventing bank panics is to insure depositors against losses. The introduction of federal deposit insurance in the Banking Act of 1933 is one of the most important reasons for the absence of banking panics in subsequent decades. ${ }^{46}$ If depositors know that their claims are guaranteed by the federal government, then they have little incentive to withdraw funds from banks in the event of bad news. A banking system whose liabilities consist mostly of insured deposits is virtually panic proof as long as the federal government remains solvent.

42. This idea can be captured in a number of ways. See, e.g., Andrei Shleifer \& Robert Vishny, Liquidation Values and Debt Capacity: A Market Equilibrium Approach, 47 J. FIN. 1343 (1992) (focusing on liquidity constraints and fire sales), Enrico Perotti \& Javier Suarez, A Pigowvian Approach to Liquidity Regulation, 7 INT'L J. CENT. BANKING 3 (2011) (focusing on debt maturity and sudden withdrawals).

43. See Calomiris \& Gorton, supra note 6.

44. WALter BAGEHOT, LOMBARD STREeT: A DESCRIPTION OF THE MONEY MARKET

(1873).

45. David C. Wheelock, The Fed's Formative Years (1913-1939), FED. RES. HIST., http:/www.federalreservehistory.org/essays/feds_formative_years [http://perma.cc/N75R-RK86]. For a comprehensive account of the Federal Reserve's history, see PETER CONTI-BROWN, THE POWER AND INDEPENDENCE OF THE Federal ReSERVE (2016); and ALLEN H. MELTZER, A HiSTORY OF THE FEDERAL RESERVE, VOLUMES 1 AND 2 (2003).

46. BARR ET AL., supra note 38 at 47-52. 
Deposit insurance, however, also eliminates the incentives of depositors to monitor bank risk. As a result, deposit insurance exacerbates another market failure in banking - risk shifting. Risk shifting arises from limited liability and the agency conflict between shareholders and depositors in a bank. ${ }^{47}$ Suppose a bank raises deposits to finance its loans. Once the terms of the deposit contract have been fixed, the bank has an incentive to increase the risk of its loans. Any additional gains go to shareholders, while additional losses (over and above what would wipe out the shareholders) are borne by the depositors. Such risk shifting or asset substitution is a concern in any entity with both equity and debt, but deposit insurance magnifies this problem by relieving depositors of the burden of monitoring banks.

Deposit insurance instead places this responsibility in the hands of bank regulators. ${ }^{48}$ In theory, bank regulators could force banks to internalize the risks they impose on depositors through deposit-insurance premiums. Historically, however, the FDIC has charged a basically flat premium. ${ }^{49}$ Unsurprisingly, flat insurance premiums do little to solve the problem of risk shifting. More formally, in a deposit insurance scheme where banks pay a fixed price for insurance, bank shareholders own a put option on the value of bank assets with a strike price that is equal to the maturity value of the outstanding debt. ${ }^{50} \mathrm{~A}$ bank operating under such a scheme has strong incentives to raise the value of this option by increasing its asset risk and/or reducing its ratio of equity relative to debt.

Recognizing the incentives faced by banks, bank regulators have developed a number of additional tools, which fall under the rubric of prudential regulation, to monitor and control bank risk taking. These measures operate as a substitute for risk-based deposit insurance premiums. Prudential regulation operates through restrictions on bank lending, such as limits on portfolio concentration and related transactions, and restrictions on the liability side of the balance sheet, such as capital and liquidity requirements. Prudential regulations are enforced through both reporting requirements and regular bank examinations.

Capital requirements are perhaps the most important tool to address such prudential concerns. ${ }^{51}$ Capital requirements have been used informally as part of the examination system since its beginnings. Binding capital requirements were introduced in the United States in the 1980s. ${ }^{52}$ Since that time U.S. capital requirements have, with some exceptions, moved in concert with the

47. Michael Jensen \& William Meckling, Theory of the Firm: Managerial Behavior, Agency Costs and Ownership Structure, 3 J. FIN. ECON. 305 (1976).

48. Fischer Black et al., An Approach to the Regulation of Bank Holding Companies, 51 J. Bus. 379 (1978)

49. Risk-based premiums were only introduced through the Federal Deposit Insurance Corporation Improvement Act of 1991, Pub. L. No. 102-242, 105. Stat. 2236 (1991).

50. Robert C. Merton, An Analytic Derivation of the Cost of Deposit Insurance and Loan Guarantees, 1 J. BANKING \& FIN. 3 (1977).

51. BARR ET AL., supra note 38 , at 259 .

52. Id. at 285-307. 
international standards promulgated by the Basel Committee on Bank Supervision. $^{53}$

The idea behind increasing bank capital or equity through such requirements are straightforward. ${ }^{54}$ First, an increase in capital lowers the likelihood of panics by non-insured depositors and other bank debt holders because there is a larger equity cushion to avoid losses. Second, holding ownership shares constant, an increase in capital weakens bank shareholders' incentives to increase bank risk. Shareholders have more to lose before debt holders experience a loss. Finally, by regulating the liability side of the balance sheet, capital requirements allow regulators to avoid, at least to some extent, exercising judgment over what investments banks make. ${ }^{55}$

The regulatory response to the recent financial crisis can be understood, at least on the banking side, as an expansion of the pre-existing framework of central bank support, debt guarantees, and prudential regulation. While the details of this expansion were complex, they are broadly consistent with two principles. First, the U.S. government will support the entire short-term debt market in the event of a market-wide panic. ${ }^{56}$ This includes Federal Reserve loans to bank and non-bank institutions that issue panic-prone debt as well as purchases of such debt. It also includes expanding the effective quantity and scope of short-term debt guarantees as necessary to quell a market panic. In the midst of the crisis in 2008, the FDIC raised the amount of insured deposits per account to $\$ 250,000^{57}$ and, more importantly, the Treasury Department temporarily guaranteed all claims on participating money market funds. ${ }^{58}$ Second, capital and liquidity requirements remain the primary regulatory tool to counteract the externality created by short-term bank debt. The Dodd-Frank Act of 2010 and its implementing regulations raise capital requirements for large bank holding companies and introduce stress tests to ensure that bank capital remains adequate under stressed conditions. ${ }^{59}$ They also create a set of new liquidity requirements and accompanying stress tests that serve a similar

\footnotetext{
53. Id.

54. Consistent with the banking literature, I will use the term bank capital to refer to bank equity.

55. Prasad Krishnamurthy, Rules, Standards, and Complexity in Capital Regulation, 43 J. LEGAL STUD. 273 (2014).

56. See ERIC POSNER, LAST RESORT: THE FINANCIAL CRISIS AND THE Future of BAILOUTS (2017) (arguing that future bailouts will inevitably occur and are generally beneficial). Horacio Spector made a similar argument about beneficial government intervention in the context of the Argentinian financial crisis of the early 2000 s. Spector, supra note 28.

57. Press Release, Fed. Deposit Ins. Corp., Emergency Economic Stabilization Act of 2008 Temporarily Increases Basic FDIC Insurance Coverage from $\$ 100,000$ to $\$ 250,000$ Per Depositor (Oct. 7, 2008), http:/www.fdic.gov/news/news/press/2008/pr08093.html [http://perma.cc/S8KY-DJ4N].

58. Press Release, U.S. Dept. of Treasury, Treasury Announces Temporary Guarantee Program for Money Market Funds, (Sept. 29, 2008), http:/www.treasury.gov/press-center/pressreleases/Pages/hp1161.aspx [http://perma.cc/MTH9-DY8K]
}

59. BARR ET AL., supra note 36 , at 307-33. 
purpose. While there are some novel regulatory elements to these schemes, ${ }^{60}$ they are broadly consistent with the Basel principles described above.

Was doubling down on the existing regulatory framework the only feasible response to the financial crisis? One cannot fault policymakers for sticking with a known paradigm, especially when the costs and benefits of other alternatives were poorly known. But it would be an equal mistake not to look outside the bounds of bank regulation orthodoxy at alternative modes of regulation. There are a number of reasons to be skeptical of the ability of the existing framework to ensure a stable banking system.

Capital and liquidity requirements may prove insufficient as tools to control bank risk taking. As described above, these requirements are a response to the fragility of banks' financial structure, the externalities created by banking panics, and the added incentives for risk taking created by implicit and explicit government guarantees. They are constrained in fundamental ways by the inability of regulators to observe and price bank risk taking with great accuracy. Just as this inability limits the usefulness of deposit insurance premiums in the presence of risk shifting, it also places important limits on capital requirements. ${ }^{61}$

To be effective, capital requirements should be higher for banks that hold riskier assets. Imposing a capital requirement also changes a bank's risk-shifting calculus. An increase in required capital can lead a bank to increase its asset risk. ${ }^{62}$ Capital requirements must therefore also be able to counteract banks' strategic response to their adoption. Consistent with this logic, the history of capital requirements has been one of ever-increasing complexity in the tools employed to measure bank risks. It has also been marked by the extensive devolution of this task to banks themselves. ${ }^{63}$

Of course, the need to monitor bank risk taking diminishes if capital requirements can be set at an arbitrarily high level. A regulated banking system funded with hardly any short-term debt has little chance of experiencing a largescale panic. On the other hand, it would not be much of a banking system. Investors demand for the safe, highly liquid debt that banks issue implies that banking, as a functional if not a legal matter, will simply take place outside of the regulated banking system. ${ }^{64}$

Capital requirements do not answer the question of whether or how to regulate banking activity that takes place outside of banks or bank holding companies. In the medium to long run, capital requirements set at levels high enough to constrain bank risk only determine the size of the regulated banking

\footnotetext{
60. Dodd-Frank Act introduces a novel system of stress tests that come under the category of macroprudential regulation. Id.

61. Gary Gorton, Bank Regulation When 'Banks' and 'Banking' are not the Same, Oxford Review of Economic Policy, 10 OXFORD REV. ECON. POL'Y 108 (1994).

62. XAVIER FREIXAS \& JEAN-CHARLES ROCHET, MICROECONOMICS OF BANKING 291$96(1997)$

63. See Krishnamurthy, supra note 55 (recounting the history of this devolution).

64. Gorton, supra note 61.
} 
system relative to the unregulated one. ${ }^{65}$ The Dodd-Frank Act attempts to address this issue by giving the Financial Stability Oversight Council (FSOC) authority to designate nonbank financial institutions as systemically important and subject them to regulation by the Federal Reserve. ${ }^{66}$ Thus far, this process has not produced a coherent set of principles for either designating such institutions or regulating designated institutions. ${ }^{67}$ Setting aside the legal issues that have beset the FSOC's authority, the FSOC's designation decisions have not focused on those activities and institutions that are the most direct substitutes for banking activity.

These weaknesses of existing regulation - viewed against the background of implicit and explicit guarantees - suggest a specific agenda for the search for an alternative regulatory model. First, it should reduce bank incentives to increase risk in ways that do not require regulators to directly observe it. Second, it should accommodate the migration of banking activity outside the regulated banking system. In this Article, I suggest that the competitive restrictions in New Deal bank regulation, despite their noted flaws, provide a historical example of just such a model.

\section{Restrictions on Competition}

It would be naïve to think that contemporary issues in financial regulation could be resolved by simply reinstituting past practices. Nevertheless, the past offers a laboratory of examples from which the present can draw important analogies, if not direct blueprints. New Deal banking regulation is an especially salient example to consider because it overlaps with the "quiet period" in U.S. financial regulation. Most of the edifice of New Deal banking regulationcentral bank lending, deposit insurance, and prudential regulation-remains intact and has even grown in scope and intensity since its inception. What no longer remains are the numerous competitive restrictions - on price, product, entry, and location expansion - that New Deal regulation placed on banking. Political economy aside, such restrictions have gone out of intellectual fashion for a reason. Textbook economics clearly identifies the distortions they introduce into economic decision making and their associated costs.

This Article nevertheless seeks to rehabilitate the regulatory role of competitive restrictions in New Deal banking. These features of the New Deal regulation had beneficial consequences - both for controlling bank risk taking and for regulating the boundary of banking activity - that may be helpful in

65. Id.

66. BARR ET AL., supra note 38 , at 698

67. For a comprehensive account of the FSOC's structure, authority, and possible justifications, see Daniel Schwarcz \& David Zaring, Regulation by Threat: Dodd-Frank and the Nonbank Problem, 84 U. CHI. L. REV. 1813 (2017). For a thoughtful institutional analysis of the Federal Reserve's regulatory powers, see Kathryn Judge, The Federal Reserve: A Study in Soft Constraints, 78 L. \& CONTEMP. PROBS. 65 (2015) 
rethinking the future of banking regulation. Section II.A analyzes the legal and regulatory mechanisms through which competitive restrictions created and preserved the ability of banks to earn rents or super-competitive profits. Section II.B then describes the critique of these restrictions, focusing on the publicchoice argument of George Stigler that they served largely as a means of organizing and enforcing a banking cartel. Section II.C concludes with an account of the demise of these restrictions and the various social and economic forces that were responsible for it. This analysis sets the stage for Part III, which suggests that the benefits of these restrictions are best understood by embracing the public choice critique. Properly understood, creating rents for the banking industry can have distinct regulatory benefits in addition to costs.

\section{A. The Fierce Urgency of NOW}

I begin with a parable of competitive restrictions in bank regulation just as they were to enter a period of sunset. The moral of the story is that these aspects of bank regulation appear to be textbook examples of regulatory capture and, more particularly, of the use of state power to create and enforce a banking cartel. I illustrate these arguments using two classic articles written on the subject by George Stigler. Stigler's account of both regulation and oligopoly were central to what became known as the public-choice view of regulation. I then suggest that it is precisely through this public-choice lens that we can also understand some of the benefits of competitive restrictions.

In 1972, the Supreme Judicial Court of Massachusetts removed a seemingly innocuous brick from the edifice of the New-Deal banking system. The Court, in Consumer Savings Bank v. Commissioner of Banks, considered whether a mutual savings bank subject to Title XII, Chapter 168 of the Massachusetts General Laws had the authority to "arrange for the transfer of funds from savings accounts by withdrawal orders in negotiable form without requiring the depositor or his representative to appear at the bank's offices." ${ }^{68}$ It decided that mutual savings banks did indeed have such authority. ${ }^{69}$

The decision provoked a regulatory maelstrom. The Federal Deposit Insurance Corporation (FDIC) immediately enacted a rule to ensure that FDICinsured banks could not follow suit that is except in Massachusetts. ${ }^{70}$ Congress stepped in with alacrity to put out the fire. Section 2 of Public Law No. 93-100, passed in 1973, declared that "(n)o depository institution shall allow the owner of a deposit or account on which interest or dividends are paid to make withdrawals by negotiable or transferable instruments for the purpose of making transfers to third parties, except that such withdrawals may be made in ...

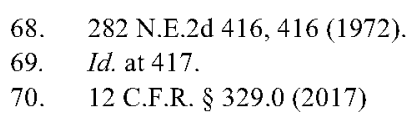


Massachusetts." 71 The term depository institution was defined broadly in the Act to include FDIC-insured banks, state banks, savings banks, mutual savings banks, and federal and state-chartered savings and loan associations. ${ }^{72}$ The Massachusetts revolution in "withdrawal orders in negotiable form" had been contained, if not fully thwarted.

How could a little-known - certainly to the general public - 1972 case on the rights of Massachusetts-chartered and operated mutual savings banks to offer "negotiable order of withdrawal" (NOW) accounts result in FDIC rulemaking and Congressional legislation in less than a year? What was the fierce urgency of NOW? Just a year earlier George Stigler, in his article The Theory of Economic Regulation, had delivered a pointed explanation for this interplay between the banking industry and its regulators: "as a rule, regulation is acquired by the industry and is designed and operated primarily for its benefit."

It is undeniable that bank regulation acted to create cartel profits for banks. In fact, Stigler himself provided the paradigmatic framework with which to understand such cartel behavior. In his 1964 article, The Theory of Oligopoly, Stigler set out to reconcile the universal desire of oligopolists

to collude to maximize joint profits ... with facts, such as that collusion is impossible for many firms and collusion is much more effective in some circumstances than in others. The reconciliation is found in the problem of policing a collusive agreement, which proves to be a problem in the theory of information. ${ }^{74}$

According to Stigler's now-textbook account, ${ }^{75}$ a successful cartel must be able to come to an agreement with respect to the products or services offered and enforce the terms of that agreement. Enforcement requires an ability to detect any deviation from the agreement and to punish those who deviate by quickly and completely removing the resulting benefits. ${ }^{76}$ The success of enforcement depends crucially on the information environment of the cartel. ${ }^{77}$

It would be difficult to come up with a better example of regulation operating to enforce a cartel than New Deal bank regulation. ${ }^{78}$ Consider first the

71. Pub. L. No. 93-100, 87 Stat. 342 (1973).

72. Id.

73. Stigler, supra note 1 , at 3 .

74. George Stigler, A Theory of Oligopoly, 72 J. POL. ECON. 44 (1964).

75. See, e.g., Carl Shapiro, Theories of Oligopoly Behavior, in HANDBOOK OF INDUSTRIAL ORGANIZATION VOLUME 1 (Richard Schmalensee \& Robert Willig eds., 1989) (summarizing theories of oligopoly behavior).

76. Stigler, supra note 74.

77. These insights were subsequently formalized using the tools of game theory in Edward J. Green \& Robert Porter, Noncooperative Collusion Under Imperfect Price Information, 52 ECONOMETRICA, 87 (1984); Dilip Abreu et al., Optimal Cartel Equilibria with Imperfect Monitoring, 39 J. ECON. THEORY 251 (1986).

78. Stigler explicitly noted the role that entry and price restrictions by the FDIC and the Federal Home Loan Bank Board played in preserving the competitive position and profits of the banking 
condition that a cartel must come to an agreement on price. New Deal banking regulation explicitly fixed the rates at which banks borrowed. The Banking Act of 1933 prohibited the payment of interest "directly or indirectly by any device whatsoever ... on any deposit which is payable on demand" by member banks of the Federal Reserve. ${ }^{79}$ The Act also directed the Federal Reserve Board (FRB) to regulate the rates of interest paid by member banks on time and savings deposits. ${ }^{80}$ Analogous prohibitions on deposit interest and limits on time and savings deposits were established by the FDIC for FDIC-insured banks in $1935^{81}$ and by the Federal Home Loan Bank Board (FHLBB) for savings and loan banks that were insured by the FSLIC in $1966 .{ }^{82}$ Moreover, when state legislatures attempted to set ceilings on lending rates through usury laws, bank regulation helped banks to minimize the losses from such ceilings. ${ }^{83}$ There can be no surer way for a bank to make profits than through regulations that enable them to borrow low and lend high.

As Stigler also pointed out, "collusion normally involves much more than 'the' price" because "even with a single, physically homogenous product, the profits will be reduced if differences among buyers are ignored." ${ }^{\prime \prime 4}$ As a result, "a price structure of some complexity will usually be the goal of collusive oligopolists." ${ }^{25}$ Stigler specifically mentioned two dimensions of buyer difference - the size and urgency of purchase - that a cartel would find it useful to distinguish in setting prices. ${ }^{86}$

Consistent with this observation, the Interest Rate Adjustment Act of 1966 required the three federal agencies with interest rate-setting powers-FRB, FDIC, and FHLBB - to consult with one another in determining rates. Consultation is, after all, a prerequisite to any complicated agreement. ${ }^{87}$ The statute clearly contemplated an agreement that would take into account differences among buyers. The agencies were authorized to limit the rates to be paid on time and savings deposits, and they were further authorized to:

industry. Stigler, supra note 73, at 5; see also Sam Peltzman, Entry in Commercial Banking, 8 J.L. \& ECON. 11 (1965) (providing evidence that regulation limited entry in banking markets).

79. Banking Act of 1933, Pub. L. No. 73-66, 48 Stat. 162 (1933).

80. Id. All nationally chartered banks were member of the Federal Reserve System. State-chartered banks could elect to be member banks.

81. Banking Act of 1935, ch. 614, \$. 101, 49 Stat. 684.

82. Interest Rate Adjustment Act of 1966, Pub. L. No. 89-597, 80 Stat. 823. Savings and loan banks were limited in their ability to offer demand deposits.

83. National banks, which are regulated by the Office of the Comptroller of the Currency (OCC), were permitted to charge rates in accordance with the laws of the State where the bank is located. The OCC interpreted federal banking law to allow national banks to charge the highest available rate for a lender in a particular state, even if the lender to which the highest rate applied was not a bank. 12 C.F.R. $\$ 7.7310$ (2017). Federal law also permitted national banks to charge rates one percent higher than the federal discount rate, even if the resulting rate would violate state usury law. 12 U.S.C. $§ 85$ (2018).

$$
\begin{aligned}
& \text { 84. Stigler, supra note } 74 \text {, at } 45 . \\
& \text { 85. Id. } \\
& \text { 86. Id. } \\
& \text { 87. Pub. L. No. } 89-597,80 \text { Stat. } 823 \text { (1966). }
\end{aligned}
$$


prescribe different rate limitations for different classes of deposits, shares, or withdrawable accounts, for deposits, shares, or withdrawable accounts of different amounts or with different maturities or subject to different conditions regarding withdrawal or payment, according to the nature or location of such members or institutions or their depositors, shareholders, or withdrawable accountholders or according to such other reasonable bases as (the agency) may deem desirable in the public interest. ${ }^{88}$

Interest rate ceilings on deposits and savings accounts, like all price controls, created the opportunity for a competitor to offer a higher rate and steal bank customers. This is exactly what took place in Massachusetts in 1972. Massachusetts had its own state-run insurance scheme for mutual savings banks. As a result, its mutual savings banks were not bound by any of the federal bank regulators - FDIC, the OCC, the FRB or the FSLIC. ${ }^{89}$ This freedom from federal regulation presented a competitive opportunity. The negotiable order of withdrawal (NOW) allowed the owner of a savings account to be able to make transfers to a third party. The owner could then receive the higher interest rate permitted for savings accounts while retaining the ability to make payments to third parties that was the hallmark of a deposit or transaction account.

What was at stake for the banking cartel in preventing such accounts? Just about everything. FDIC-insured banks had a near monopoly over the ability to offer demand deposits. In 1970, FDIC-insured banks held $\$ 482$ billion in total deposits, and they paid no interest on over fifty percent of this total $(\$ 247$ billion) ${ }^{90}$ If Massachusetts mutual banks could offer interest-paying NOW accounts, they would attract demand deposits from banks. They would also attract savings deposits from savings-and-loan banks that were unable to offer demand deposits. Banks in Massachusetts would have to respond by obtaining regulatory permission to offer their own NOW accounts combining transaction services with interest on savings. If NOW accounts spread nationwide, this would threaten $\$ 247$ billion - or about one quarter of 1970 U.S. GDP ${ }^{91}$ - in interest-free deposits for FDIC-insured banks. The Massachusetts example also illustrates the extent to which regulatory competition could undermine a regulation-created cartel. The Massachusetts savings banks constituted a competitive threat only because of the subsidy they received from the state-run insurance program. Without deposit insurance, they would not be able to attract deposits from FDIC-insured banks.

88. Id.

89. The OCC only regulated banks with national charters, the FRB only regulated state banks if they chose to become members of the Federal Reserve, and federal interest rate caps applied to state-chartered commercial banks and savings and loan banks only if they were insured by the FDIC or the FSLIC. Massachusetts mutual banks did not fall under any of these categories.

90. Historical Statistics on Banking, FED. DEPOSIT INS. CORP., http://www5.fdic.gov /hsob/HSOBRpt.asp [http://perma.cc/D86U-RWQC].

91. Gross Domestic Product, FED. Res. BANK ST. Louls (Fed. 28, 2018), http:/ fred.stlouisfed.org/series/GDP [http://perma.cc/6XSS-3BUL]. 
The New Deal regulatory framework was, however, effectively designed to facilitate detection and punishment of deviations from the cartel agreement. The institutional channels of detection and punishment could be readily seen in the Massachusetts case. The Massachusetts Commissioner of Banks, the FDIC, and Congress all stepped in, with alacrity, to prevent nation-wide competition in NOW accounts, while simultaneously allowing banks to offer them within Massachusetts. The competitive threat to banks arose from outside the umbrella of federal banking regulation. The price deviation was nevertheless detected by the Massachusetts Commissioner of Banks when the Consumer Savings Bank sought regulatory approval for its plan to offer negotiable withdrawals from savings accounts. The approval process for all new accounts was designed to reveal this information to the regulator. And while it is possible that the good Commissioner would have immediately recognized the national threat to the banking industry posed by Consumer Savings Bank's application, it is unlikely that the Commissioner did not receive advice on this issue from the state's banking interests. Massachusetts' banks that were competitors of the savings bank were well positioned to monitor the account offerings of their rivals as well as their regulatory applications and to inform the Commissioner of any disguised attempts to undermine the system. The Commissioner denied the request, stating that negotiable withdrawal would create a new account with features that were prohibited under Massachusetts law. But this first attempt at punishment failed when the Supreme Judicial Court of Massachusetts overturned the Commissioner's denial.

The court's decision provoked a public response from the industry and from regulators. Shortly after the decision, the American Banker warned that the "entry of savings banks into the checking account business is potentially disastrous for commercial banks in the commonwealth."92 The Massachusetts Commissioner agreed that

There is a delicate balance of power between commercial banks and thrift institutions. Different statutory and regulatory provisions over the years, at both the state and Federal level, have been designed to maintain this equilibrium, in the interest of the banks, and, ultimately, of the public. Every expansion of the powers of one segment of the banking industry must have an adverse effect on other types of institutions unless some accommodation is made to extend their powers as well. ${ }^{93}$

The President of the Boston Federal Reserve also saw the case's "potential for disrupting the financial stability of the banking structure." 94 The FRB

92. Alan J. Kaplan, Comment, The Negotiable Order of Withdrawal (NOW) Account: 'Checking Accounts' for Savings Banks? 14 B.C. L. REV. 471, 488 (1973) (quoting Freyda P. Koplow, Massachusetts Legal Decision Confuses Savings Bank Status, AM. BANKER, SEPT. 25, 1972, at 17).

93. Kaplan, supra note 92, at 488 (quoting Koplow, supra note 92, at 17).

94. Id. (quoting Boston Globe, Oct. 6, 1972, at 37 (statement of Frank Morris, President of the Federal Reserve Bank of Boston)). 
immediately proposed regulation that would use its clearing authority to prevent this possibility. Any nonmember bank that sought to utilize the Federal Reserve system to clear NOW items would be required to maintain a clearing account with the FRB equal to three percent of its NOW deposits. ${ }^{95}$ Three percent just happened to be the reserve requirement for FRB member savings accounts. In effect, the FRB proposed to institute reserve requirements on Massachusetts mutual savings banks offering NOW accounts through its control of the payment system. ${ }^{96}$ Despite its ingenuity, the proposal was not pursued.

The FDIC did, however, issue rules that permitted banks in Massachusetts to establish NOW accounts while making it clear that banks in other states were still prohibited from doing so. ${ }^{97}$ Congress subsequently extended this rule to all banks. ${ }^{98}$ As a result of this swift regulatory and legislative response, mutual banks in Massachusetts were prevented from gaining any lasting competitive advantage. This sent a clear message of deterrence to potential competitors in other states. In Massachusetts, mutual banks now had to compete with banks that could offer NOW accounts combining transactional services with higher interest rates. Banks' ability to earn revenues remained unchanged, but borrowing costs were now higher across all institutions. The price deviation had been detected and successfully punished, at a collective cost to the industry.

\section{B. Public Choice}

This example is just one instance of how New Deal regulation acted to protect profits within the banking industry. In addition to pillars of central bank support, deposit insurance, and prudential oversight, New Deal bank regulation maintained an elaborate system of price, product, entry, and location restrictions that shielded banks from competition. As we have seen, the Banking Act of 1933 controlled prices.

The scope of banking products or services was regulated by the GlassSteagall Act of 1933. Section 16 of the Act prohibited national banks from underwriting, selling, or dealing in securities, while Section 20 prohibited such banks from affiliating with any firms principally engaged in these activities. ${ }^{99}$ Section 21 of the Act, in turn, prohibited firms that issued, underwrote, sold, or distributed securities from receiving deposits. These restrictions constituted a quid pro quo between the banking and securities industries. Banks maintained control over deposits, while securities firms operating as broker-dealers were

95. See 38 Fed. Reg. 26,469 (1973).

96. Alan Kaplan, Federal Legislative and Regulatory Treatment of NOW Accounts, 91 BANKING L.J. 442 (1974).

97. $\quad 12$ C.F.R. $\S 329.0(1972)$

98. Pub. L. No. 93-100, 87 Stat. 342 (2017).

99. Other sections of the Act extended these prohibitions to state banks that were members of the Federal Reserve System and state nonmember banks that were insured by the FDIC. Section 20 was repealed by the Gramm-Leach-Bliley Act of 1999. See BARR ET AL., supra note 38, at 4758. 
protected from competition by banks. The restrictions on bank activities even had a benefit to banks. Services like brokerage and investment advice are complements to offering deposits. Bank competition in complementary services would undermine the effect of price and entry restrictions in the deposit market. ${ }^{100}$ Restrictions that prevented banks from engaging in securities-related activity actually helped them to avoid competing away the benefits of their control over deposits.

In the case of entry, the FDIC's control over federal deposit insurance gave it effective power over new charters in banking. ${ }^{101}$ The Banking Act of 1935 set up a system of charter approval in which almost all new bank charters had to be approved by a federal banking regulator. ${ }^{102}$ Before granting a new charter, regulators were required to assess the financial history and condition of a bank, its capital adequacy, its future earnings prospects, and "the convenience and needs of the community to be served by the bank." ${ }^{03}$ Charter applications were frequently denied on these grounds, ${ }^{104}$ and most empirical evidence suggests that the federal charter approval system lowered bank entry relative to what would have prevailed in its absence. ${ }^{105}$

State and federal law imposed limits on bank location through restrictions on bank branching both within and across state lines. The Douglas Amendment to the Bank Company Holding Act of 1956 prohibited out-of-state bank holding companies from acquiring a bank without the permission of the target bank's state regulator. At the time, no state provided such approval. Most states had laws that also limited within-state branching. Some states prohibited branching entirely, while others restricted branching to contiguous counties or to a prescribed geographic distance from the bank's headquarters. ${ }^{106}$ The competitive equality doctrine in federal banking law meant that these branching restrictions also applied to nationally chartered banks operating in those states. The empirical

100. For example, even if the government fixes the price of left shoes, if shoemakers can freely set the price of right shoes, the market for shoe pairs will still be competitive.

101. State-chartered banks could not effectively compete unless they were insured by the FDIC

102. The Office of the Comptroller of the Currency had responsibility for national bank charters, the Federal Reserve Board had responsibility for state banks that were member of the Federal Reserve System, and the Federal Deposit Insurance Corporation had responsibility for state banks that were insured by the FDIC. Chartering authority lay solely in the hands of state regulators for state banks that did not receive FDIC insurance and were not Federal Reserve member banks. See BARR ET AL., supra note 38 , at $157-83$

103. Banking Act of 1935, Ch. 614, Sec. 101, 49 Stat. 684

104. Peltzman, supra note 78; David A. Alhadeff, A Reconsideration of Restrictions on Bank Entry, 76 Q.J. ECON. 246 (1962).

105. See Peltzman, supra note 78 .

106. Dean F. Amel, State Laws Affecting the Geographic Expansion of Commercial Banks (1993) (unpublished manuscript), http://raser.stlouisfed.org/scribd/?title id=4954\&filepath=/files /docs/historical/frb/Amel_StateLawsAffectingtheGeographicExpansion.pdf $\quad[\mathrm{http} / /$ perma.cc/QVT3ECGL]. 
evidence is strong that these restrictions limited the scale of bank entry and expansion. ${ }^{107}$

For most of the last fifty years, scholars have inveighed against these features of New Deal bank regulation. Price controls introduce a number of distortions into the deposit market. Depositors are less likely to save because of the lower returns to saving. Banks can compete around these restrictions by offering discounts on complementary products, which leads consumers to purchase bundles of financial services that they value less they would in the absence of such controls. For this reason, price and product regulation usually come together. Below-market deposit rates result in a regressive transfer of wealth from bank depositors to bank equity holders. This view was shared by economists across the political spectrum, including luminaries such as Milton Friedman ${ }^{108}$ and James Tobin. ${ }^{109}$ According to Friedman, the system of deposit rate controls "subjected the commercial banking system - and the financial system more broadly - to severe structural adjustments for no social gain whatsoever."

The separation of commercial and investment banking in the Glass-Steagall Act also came under attack. Commercial banking and broker-dealer services are complementary for many bank customers. Artificially separating these activities foregoes operational efficiencies and raises the cost of providing services. It also results in double markups to customers if both commercial and investment banks possess some degree of market power. Preventing commercial banks from pursuing alternative income streams leads, it was argued, led to an inefficiently diversified and therefore fragile banking sector. For Jonathan Macey, one of the leading legal scholars of banking regulation, "any notion that Glass-Steagall can be justified on grounds that commercial banks are somehow made safer by the Act's prohibitions is clearly misguided, since the law, if anything, accomplishes precisely the opposite result." 10

A similar critique was levied against entry and location restrictions. These restrictions lead to higher prices for deposit and lending services. Perhaps more importantly, they create a fragmented and undiversified banking system. According to the noted economist and financial historian Charles Calomiris, the

107. See Jith Jayaratne \& Philip Strahan, Entry Restrictions, Industry Evolution, and Dynamic Efficiency: Evidence From Commercial Banking, 41 J.L. \& ECON. (1998) (providing evidence that more efficient banks expanded after deregulation).

108. See Milton Friedman, Controls on Interest Rates Paid by Banks, 2 J. MONEY, CREDIT \& BANKING 15 (1970) (arguing that controls on interest rates are not an effective tool of monetary policy).

109. James Tobin, Deposit Interest Ceilings as a Monetary Control, 2 J. MONEY, CREDIT \& BANKING 4 (1970) (arguing that deposit ceilings have a modest effect on monetary conditions but pernicious effects through the suppression of interest rates to small savers and the risks created in savings and loan associations).

110. Macey, supra note 25 , at 13 . 
New Deal reforms "not only failed to address the key structural problems that had caused the crisis, they actually reinforced those structural weaknesses."

If the effects of price, product, entry, and location restrictions are so pernicious, then what led to their adoption in the first place? According to Calomiris, "the central lesson of the 1930s reforms was that comprehensive, hasty, post-crisis reform initiatives maximize the potential for logrolling, which facilitates the enactment of ill-conceived ideas and special interest measures that otherwise would not have passed." 112 Some aspects of this misdiagnosis were quite specific. Calomiris recounts how limits on interest rates and the separation of commercial and investment banking were partly an intellectual offspring of a misguided theory of central banking - the real bills doctrine - and the creation of federal deposit insurance arose from a desire to preserve unit or single-branch banking. 113

Other aspects of the misdiagnosis were quite general. In their influential account, law and economics scholars Daniel Fischel, Andrew Rosenfield, and Robert Still write that

[W] hat is most striking about the New Deal program of banking regulation is its similarity to the programs of public utility and common carrier regulation, many of which (such as airline, motor carrier, and telecommunications regulation) were established during the same period. The essential features of the New Deal banking regulation were entry control, price control, market allocation through the forced separation of commercial banking from investment banking and securities activities, and close supervision of investments and related activities. These were the essential features of airline, surface transportation, and communications regulation as well. The similarity of these regulatory policies was not coincidental. ${ }^{114}$

For these authors, the similarity of banking to utility regulation arose from a common, misguided account of the harms of competitive markets. They echo what I have called the "orthodox" view in noting that "banks are different from other types of firms in that they are more susceptible to me-first behavior by creditors. Federal deposit insurance is best understood as a regulatory response to this prisoner's dilemma faced by bank depositors." 15 In contrast, anticompetitive regulations in banking "have nothing to do with the reasons why banks are different from other types of firms and thus serve no useful social purpose." $" 116$

\begin{aligned} \hline 111. & Calomiris, supra note 25, at 541. \\ 112. & Id. \\ 113. & Id. \\ 114. & Daniel R. Fischel et al., The Regulation of Banks and Bank Holding Companies, \\ 73 VA. L. REV. $301,302-03(1987) &$. Id. at 306 \\ 116. & Id. at 338.\end{aligned}


The most damning critique, however, was made by George Stigler and other scholars who advanced a public choice view of these aspects of New Deal banking regulation. According to public choice theory, industry rent seeking provided a better explanation for the institutional form of regulation than the folly, much less wisdom, of public officials. Stigler's account of regulation emphasized four key policies that industries would seek from the state: (1) direct subsidies, (2) control over entry, (3) suppression of substitutes and promotion of complements, and (4) control over prices. ${ }^{117}$ As described above, it is difficult to dispute how well Stigler's account fits these patterns in New Deal bank regulation. Regulatory restrictions on price, product, entry, and location appear perfectly designed to deliver super-competitive profits or rents to the banking industry. The preceding parable of the NOW account is just one example of the numerous attempts over this period by institutions to try to capture some of the cartel profits created through bank regulation. In each instance, banking regulators, acting through regulation designed to reveal these cartel threats, brought to bear their enforcement power - often creatively - to punish and deter them. This regulatory game evidenced itself in arcane and seemingly nonsensical and circular definitional disputes over terms such as "bank," "branch," "deposit account," "savings account," and "the business of banking."118

\section{Rent Dissipation}

Consistent with the Stiglerian view, competition itself played a fundamental role in the eventual demise of these restrictions. The history of gradual deregulation in U.S. banking has been recounted in a number of careful studies. ${ }^{119}$ Here, I briefly describe the main forces that undermined their role in creating rents for banks. These developments were widely celebrated by critics of the New Deal restriction, and they unquestionably resulted in economic benefits. With hindsight, we can perhaps better appreciate some of their associated costs.

Limitations on bank entry grew less important as non-bank lenders became increasingly able to compete with banks. Industrial loan companies and other non-bank finance companies expanded their presence in the loan market. The growth of the corporate bond market and the commercial paper market meant that businesses could increasingly turn to the capital markets to borrow rather than relying on loans. Geographic restrictions also conveyed less market power

117. See Stigler, supra note 1. FDIC deposit insurance and deposit rate limits acted, respectively, as a subsidy and price control.

118. The legal disputes around these categories are described in Macey \& Miller, supra note 14

119. See generally Allen Berger et a1., The Transformation of the U.S. Banking Industry: What a Long, Strange Trip It's Been, 2 BROOKINGS PAPERS ON ECON. ACTIVITY 55 (1995); Allen Berger et al., The Consolidation of the Financial Services Industry: Causes, Consequences, and Implications for the Future, 23 J. BANKING \& FIN., 135-194 (1999) (describing the causes and effects of bank deregulation over the course of the 1980 s and 90 s). 
over time. Developments in information technology made distance lending easier and cheaper. The expansion of the capital markets lessened the importance of geography to credit access. Non-bank lenders were able to expand geographically by sidestepping the legal definition of a bank branch. Moreover, as the value of geographic restrictions eroded, the restrictions themselves were lifted. ${ }^{120}$ Starting in the $1970 \mathrm{~s}$, states began to loosen their restrictions on bank branching both within and across state lines. ${ }^{121}$

Interest rate controls on deposits were undermined by a combination of high inflation and competition from deposit substitutes. Inflation and nominal interest rates were relatively low in the post-war period, but rose dramatically at the end of the 1960s. During the 1970s, inflation averaged over seven percent, with peaks that exceeded ten percent in $1974 .{ }^{122}$ This large and negative real rate of return on deposits created the opportunity for interest-bearing deposit substitutes to emerge. The two most prominent deposit substitutes that emerged were Eurodollars and money market funds. ${ }^{123}$ Eurodollars are dollardenominated deposit liabilities issued by foreign banks, mostly in Europe. Money market funds are short-term investment vehicles organized under the Investment Company Act. ${ }^{124}$ They both offered the advantage to investors - in particular, institutions and wealthy individuals of market interest rates on accounts that were similar to demand deposits issued by U.S. commercial banks. ${ }^{125}$ Importantly, the development of both these substitutes was enabled by regulatory permission. Their development had implications for both the stability of the banking system and the conduct of monetary policy. Any combination of regulatory coordination, congressional action, or judicial interpretation could plausibly have curtailed these developments, but they did not.

120. Randall S. Kroszner \& Philip E. Strahan, What Drives Deregulation? Economics and Politics of Bank Branching Restrictions, 114 Q.J. ECON. 1437 (1999).

121. See Amel, supra note 106.

122. Janet Yellen, Chair, Fed. Reserve, Inflation Dynamics and Monetary Policy, Philip Gamble Memorial Lecture (Sept. 24, 2015), http://www.federalreserve.gov/newsevents/speech /yellen20150924a.htm [http://perma.cc/7QDN-8TMX].

123. BARR ET AL., supra note 38, at 1197-1221; Marvin Goodfriend, Eurodollars, in FED. RES. BANK RICHMOND ECON. REV. 13 (1991).

124. Money market funds are investment funds that offer investors shares that are intended to maintain stable value of one dollar per share. Money market funds replicate many of the features of demand deposits such as easy withdrawal and the ability to write checks against the account. Unlike banks, they are required to hold short term, liquid securities with very low credit risk. Like Eurodollar deposits, money market funds offered yields that were well in excess of what could be obtained in a demand deposit or savings account. They invested in short-term assets such as commercial paper or Treasury Bills and offered transactional features that were similar to deposits. As a result, their yields also closely tracked the federal funds rate. The accounting rules for these funds allowed them be valued using an amortized cost value. Money market funds could maintain a stable net asset value - instead of a value that floated with market prices - and be considered a cash equivalent. Money market funds also offered checking and withdrawal features that were comparable to deposit accounts. See Barr et al., supra note 38 , at 1197-1221.

125. Eurodollar yields closely matched the federal funds rate, which frequently stood at over ten percent in the period from 1969 to 1974. See Eurodollar Deposits Rates and Effective Federal Funds Rate, FED. RES. BANK ST. LOUIS (Fed. 26, 2018), http:/fred.stlouisfed.org/series /IR3TED01USA156N [http://perma.cc/JX7X-QV66]. 
The collective pressure of these deposit-substitutes led to disintermediation, that is, the loss of funds from U.S. commercial and savings banks. As inflation accelerated again in the late 1970s and early 1980s, deposit controls were no longer feasible. The Deposit Institutions Deregulation and Monetary Control Act of 1980 phased out interest rate ceilings for banks. ${ }^{126}$ Banks also attempted to stem the outflow of deposit and savings by creating products that replicated the features of these deposit substitutes. The Garn St. Germain Depository Institutions Act of 1982 authorized commercial and savings banks to offer money market deposit accounts, which mimicked most of the features of money market fund accounts. ${ }^{127}$

The separation of commercial and investment banking suffered a similar fate. Competition again played a central role. In the $1970 \mathrm{~s}$, investment banks helped to expand the commercial paper market, which began to displace bank lines of credit as the major source of short-term funding for large organizations. Money market funds, in fact, were the one of the major purchasers of commercial paper. Banks, in turn, sought to recapture some of this lost business by acquiring the ability to underwrite commercial paper-that is, to serve as a dealer in this market. Providing broker-dealer services was a traditional province of investment banks. Squeezed between rising short-term interest rates and longterm assets such as mortgages with low interest rates, banks were eager to seek new sources of fee-based revenue by serving as a broker, dealer, and investment adviser. ${ }^{28}$

The rise of securitization and wholesale funding also brought investment banks closer to the traditional lending business of banks, particularly in mortgage markets. Investment banks played a crucial role in the originate-to-distribute model of mortgage lending, acting as providers of short-term finance for originators and as underwriters of asset-backed securities. Investment banks also maintained large portfolios of asset-backed securities on their own balance sheet both for investment purposes and to lend to their clients. In this respect, they looked more like banks. To summarize, competition from non-bank lenders pushed commercial banks into the broker-dealer business, while competition in the broker-dealer business pushed investment banks into lending.

As in the case of deposits, regulators and courts facilitated this expansion and blurring of commercial and investment bank functions. Federal bank regulators and the SEC each took a permissive view with respect to expanding the authority of their constituent institutions. Courts, faced with a series of difficult one-off determinations, a body of precedent and practice that could be flexibly interpreted, and no guiding philosophy to balance competing consideration, largely acquiesced in this process. In fact, much of the GrammLeach-Bliley Act of 1999, which removed the final barriers to associations

126. Pub. L. No. 96-221, 94 Stat. 132 (1980).

127. Pub. L. No. 97-320, 96 Stat. 1469 (1982).

128. BARR ET AL., supra note 36 , at 1197-1211. 
between banking and investment banking within a holding-company structure, served only to codify by statute what had been already accomplished through decades of agency and court decisions. ${ }^{129}$

Unsurprisingly, critics of New Deal banking regulation's restrictions on competition did not mourn their eventual erosion. However, as these restrictions gradually gave way the quiet period in banking also came to an end. The next Part describes the role of competitive forces in reviving banking instability in the United States and the scholarly reconsideration of competition in banking that it provoked. It then uses this theoretical framework to reinterpret the role that competitive restrictions played in New Deal bank regulation, focusing on the issues of bank risk taking and the boundaries of banking.

\section{Competition and Instability}

Competition in banking is not an unfettered good. If competition can result in social harm, it follows that limits on competition can mitigate some of these effects. There are of course many ways that regulation can limit competition, each with different effects. Here, I summarize the theory and evidence suggesting that the competitive restrictions in New Deal banking regulation were especially useful in limiting bank risk taking and preventing regulatory arbitrage. These insights inform how contemporary regulation could better address these two issues.

The idea that unfettered or excessive competition among banks can result in financial instability is far from new. As the New York Clearing House Association Committee concluded in its investigation of the Panic of 1857, "a bank having committed the first error of paying interest on its deposits is therefore compelled, by the necessities of its position, to take the second false step and expand its operations beyond all prudent bounds." 130 This view also dominated discussions of bank failures in the 1930s. According to Milton Friedman, "it was widely, if mistakenly, believed that these failures were the result of 'bad' banking and that 'bad' banking in turn was the result of risky loans made by banks under pressure to earn enough to pay competitive rates on deposits." 131

During the Great Depression, the idea that excessive competition could be ruinous was thought to apply to many industries. The National Industrial Recovery Act of 1933 sought to create "codes of fair competition" for each industry to limit competition with respect to prices, working hours, and wages. ${ }^{132}$ Before the Act was eventually declared unconstitutional in Schecter Poultry $v$.

\footnotetext{
129. Id. at 659-74.

130. George J. Bentson, Interest Payments on Demand Deposits and Bank Investment Behavior, 72 J. POL. ECON. 431, 431-32 (1964).

131. See Milton Friedman, Controls on Interest Rates Paid by Banks, 2 J. MONEY, CREDIT \& BANKING 15, 18 (1970).

132. Pub. L. No. 73-67, 48 Stat. 195 (1933).
} 
United States, ${ }^{133}$ hundreds of industries submitted codes of fair competition that were approved by Roosevelt's National Recovery Administration. ${ }^{134}$ The argument that unrestrained competition would have widespread, negative consequences also provided a justification for extensive regulation of entry, expansion, and pricing in a variety of industries until at least the $1980 \mathrm{~s} .{ }^{135}$

To a substantial extent, the center of gravity of these debates has moved in the direction of greater competition. In industries as diverse as transportation, telecommunications, and energy, the purview of direct regulation has subsided, while that of antitrust and competition has expanded. ${ }^{136}$ Disagreement over means aside, there are few areas of economic life where the aim of increasing competition within an industry or sector does not share substantial policy and often popular support. $^{137}$

In the case of banking, however, the key policy issues are to some extent distinct from the overwhelming concern with market power that dominates industries where direct regulation was once common and has since subsided. In this Part, I explain the case for how limits on bank competition can enhance financial stability. This body of theory and evidence arose against the demise of the role of competitive restrictions and the contemporaneous rise of instability in the banking sector.

This line of reasoning turns the public choice critique of regulation on its head. Those aspects of regulation that create a cartel also serve a distinct and useful regulatory purpose. The theory of oligopoly has proven invaluable in the design of policies to enhance competition. The case banking illustrates how, in some cases, this theory can also be deployed to beneficially constraints competition. It also illustrates why, to be effective, such constraints must exist within a suitable legal, political and economic order.

\section{A. The Reemergence of Instability}

\section{Rethinking Competition}

The stability that characterized banking in the post-war decades came to an end in the 1980s and 1990s. This period was marked by a rise in bank failures and the reappearance of large-scale government rescues, most prominently the

\footnotetext{
133. 295 U.S. 495 (1935).

134. Barbara Alexander, The Impact of the National Industrial Recovery Act on Cartel Formation \& Maintenance Costs, 76 REV. ECON. \& STAT. 245 (1994).

135. See Fischel et al., supra note 114.

136. See James Ming Chen, Speculative Undertakings: Rate Regulation as a Branch of Corporate Finance, 35 YALE J. ON REG. 779 (2018); see also Daniel Schwarcz, Ending Public Utility Style Rate Regulation in Insurance, 35 YALE J. ON REG. 941 (2018) (calling for less direct regulation of the insurance industry to reflect economic changes).

137. For the general policy arguments in favor of deregulation in these sectors, see Deregllation of Network Industries: What's Next? (Sam Peltzman \& Clifford Whinston eds., 2000)
} 
savings-and-loan crisis of the 1980s. In the midst of these developments, a scholarly literature arose that tried to explain the reemergence of banking instability.

A key challenge for this literature was to explain why regulation had been more or less effective in the prior decades. From the 1950 s to the end of the 1970 s, bank failures were exceedingly rare, averaging only a few per year. ${ }^{138}$ This was true despite the presence of a number of factors that would suggest otherwise. Banks had access to insured deposits, which eliminated the need for monitoring by depositors. The insurance premium charged to banks was basically flat, and therefore did little to blunt incentives for risk shifting. Branching restrictions both within and across state lines meant that there were thousands of banks, each of them quite undiversified and subject to considerable local economic risk. Nevertheless, it took until the 1980s for widespread banking failures to occur. ${ }^{139}$

A potential explanation could be located in the tradeoffs between bank risk taking and competition and how these tradeoffs vary as a function of other features of bank regulation - in particular, deposit insurance, asset restrictions, and capital requirements. In particular, when banks are free to choose the riskreturn profile of their assets, the incentive for risk shifting declines as the charter value of the bank increases. This implies charter value is a potential tool with which to control bank risk.

In his paper, Deposit Insurance, Risk, and Market Power in Banking, Michael Keeley provided a canonical account of this mechanism. ${ }^{140}$ If a bank possessed any degree of market power in the loan or deposit market, then this value would be capitalized in the equity value of the bank. Current owners of bank equity would lose this value in the event the bank failed or was taken over by its regulator. The greater the charter value, the more it disciplined the incentives of equity holders to avoid any increase in risk or decrease in capital that might result in insolvency. Of course, the option value of deposit insurance was, at least in theory, arbitrarily high. However, if a bank's charter value was also high then it would take a large, discrete increase in risk and/or fall in capital for the expected gain in option value to counteract the expected loss in charter value. As long as a bank regulator was capable of observing such a large increase,

138. Failures and Assistance Transactions of all Institutions for the United States and Other Areas, FED. RES. BANK ST. LOUIS (Sept. 29, 2017), http://fred.stlouisfed.org/series /BNKTTLA641N [http://perma.cc/28DV-7PHU].

139. Id.

140. Michael Keeley, Deposit Insurance, Risk and Market Power in Banking, 80 AM. ECON. REV. 1183 (1990). Alan Marcus derived this result using Merton's option approach to value bank equity and suggested that the deregulation of banking could result in general decline in bank charter value and a corresponding increase in bank risk. Alan J. Marcus, Deregulation and Bank Financial Policy, $8 \mathrm{~J}$. BANKING \& FIN., 557 (1984). 
the charter value acted to discipline bank risk taking. ${ }^{141}$ This insight was subsequently refined and extended in the banking literature.

Competition can exacerbate bank risk taking in a number of ways. ${ }^{142}$ For example, if a bank is able make investments in borrower-specific knowledge, this increases the ex post switching costs for a borrower and is a source of bank profits. In a more competitive market, banks have weaker incentives to make these investments and the switching costs for borrowers are correspondingly lower. The resulting loss of charter value from the value of bank-borrower relationship can then have the effect of increasing bank asset risk. ${ }^{143}$ As another example, if bank competition has winner-take-all features, this enhances the incentive to take risky actions that increase market share in the short run. Such winner-take-all competition could arise as a result of economies of scale in banking from technology or network effects. ${ }^{144}$

This relationship between competition and increased risk taking can hold even when manager's incentives are not aligned with those of shareholders. Less competitive environments can create rents for managers in the form of higher wages or the "quiet life." If these rents are dissipated through competition or even by increasing the alignment between shareholders' and managers' interests, the result can be an increase in bank risk taking. Rent sharing by managers also implies that the threat of bank closure is not required for charter value to play a disciplining role on risk. The threat of removing the manager will suffice.

The basic intuition that there is a tradeoff between competition and risk also survives in models that consider the effects of banking regulation. Deposit insurance, as explained above, exacerbates the incentives for risk shifting. This feature of deposit insurance can be mitigated, though not necessarily eliminated, if deposit insurance premiums are set so that bank equity holders internalize the effect of any risk shifting. ${ }^{145}$ However, appeals to risk-based deposit premiums to solve the problem of bank risk taking assume away the fundamental regulatory

141. The tradeoff between risk taking and charter value is easiest to see in the context of full deposit insurance, but exists even when banks are symmetric and equilibrium, deposit insurance fees to banks correctly reflect their asset risk. The key insight is there is still asymmetric information between debt holders and banks at the time banks choose their asset risk. Franklin Allen \& Douglas Gale, Competition and Stability, 36 J. MONEY, CREDIT \& BANKING 453 (2004).

142. This is not to say that competition can never reduce incentives for risk taking. For example, if a bank is able to lower its cost of funding by building a reputation for safety, then this mitigates risk-shifting incentives. Arnoud W.A. Boot \& Stuart I. Greenbaum, Bank Regulation, Reputation and Rents: Theory and Policy Implications, in CAPITAL MARKETS AND FINANCIAL INTERMEDIATION 262 (Chris Mayer \& Xavier Vives eds., 1993). The authors point out that bank regulations such as deposit insurance and capital requirements can make it more difficult for banks to acquire such a reputation.

143. David Besanko \& Anjan V. Thakor, Relationship Banking, Deposit Insurance, and Bank Portfolio Choice, in CAPITAL MARKETS AND FINANCLAL INTERMEDIATION, supra note 142, at 292; see also Mitchell Petersen \& Raghuram Rajan, The Effect of Credit Market Competition on Lending Relationships, 110 Q.J. ECON. 407 (1995) (demonstrating the continued importance of local lending even in the 1990s).

144. Allen \& Gale, supra note 141. In general, any feature of competition that makes a bank's profit function more convex exacerbates risk shifting.

145. See Carmen Matutes \& Xavier Vives, Imperfect Competition, Risk Taking, and Regulation in Banking, 4 EUR. ECON. REV. 1 (2000). 
problem. If bank risks were perfectly observable to regulators, the entire discussion of bank regulation would be moot.

Importantly, capital requirements do not eliminate this relationship. The standard view of capital requirements is that they force equity holders to internalize bank risk and thereby reduces risk-taking incentives. ${ }^{146}$ This view may not hold, however, if capital requirements lower the charter value of banks by raising the overall cost of capital. The net effect of a capital requirement is ambiguous as a result of these two countervailing effects. In an important paper, Hellman, Murdock, and Stiglitz show that adding deposit rate controls to a capital requirement produces a more efficient outcome. ${ }^{147}$ This result suggests that capital requirements may have limited ability to control bank risk when competition deposits is intense and when, as is empirically the case, bank shareholders are diversified. This is an important issue given the reliance of contemporary financial regulation on capital.

\section{A History of the Present}

These insights provide a theoretical framework with which to understand the rise of banking instability in the 1980s and its continuation to the present. Here, I focus on the prior period in order to highlight its continuity with the present. I show my thesis - that increased competition can lead destabilize banking system through increased risk taking - is supported by empirical evidence. This is not to say that such evidence is incontrovertible. It is important to be circumspect about the limits of causal claims regarding large-scale social processes such as banking crises. However, one could just as easily say there is no incontrovertible evidence that competition always enhances stability or never increases risk. The goal in presenting this evidence is to show that the relationship between competition and instability is empirically plausible enough to generate a policy discussion on the possible regulatory role of limits to competition. As noted above, banks faced increasing competition in both the loan and deposit markets over the course of the 1970s. Consistent with a rise in competition, measures of bank profitability began to fall. ${ }^{148}$ Both the rate of return on equity and the rate of return on assets fell steadily for commercial and savings banks from 1979 to $1991 .^{149}$ The ratio of market to book value for bank assets, a measure of the capitalized value of market power, declined from the

\footnotetext{
146. See, e.g., Frederick T. Furlong \& Michael Keeley, Capital Regulation and Bank Risk-Taking: A Note, 13 J. BANKING \& FIN. 883 (1989).

147. Thomas F. Hellman et al., Liberalization, Moral Hazard in Banking, and Prudential Regulation, 90 AM. ECON. REV. 147 (2000). The authors also show that deposit rate controls can be useful even if they are not actually binding on banks.

148. Keeley, supra note 140; Franklin Edwards \& Fredric Mishkin, The Decline of Traditional Banking: Implications for Financial Stability and Regulatory Policy, 1 ECON. POL'Y REV. 37 (1995) (documenting a decline in bank profitability).

149. Id.
} 
1950 s to the $1980 \mathrm{~s} .{ }^{150}$ Bank capital ratios also declined, suggesting that banks were operating closer to their default threshold. ${ }^{151}$

Some of this decline in profitability was undoubtedly linked to changes in interest rates. ${ }^{152}$ As I explained above, Paul Mahoney lays most of the blame for banking instability on movements in interest rates rather than deregulation. Indeed, the Volcker recession of the 1980s featured a large increase in short-term interest rates as the Federal Reserve sought to rein in inflation. ${ }^{153}$ Recessions are generally bad news for banks.

However, the relationship between interest rates, regulation, and banking instability cannot be easily separated. Volatility in interest rates tends to hurt banks because, by virtue of their short-term liabilities and long-term assets, they are heavily exposed to interest rate risk. The effects of interest rate volatility on banks are asymmetric. When interest rates rise, banks are particularly vulnerable because the interest they owe on their liabilities will rise, while the interest rate on their earnings will, in the short term, not change.

During the inflationary episodes of the 1960 s and 1970 s, controlled deposit rates provided banks with some protection against rising market interest rates. Banks may have lost market share to competitors who were willing or able to attract investors by offering higher interest rates, but banks would have also earned a larger spread on loans. In contrast, the Volcker recession took place just as these controls were phased out. As a result, banks had to fund their existing stock of lower-interest loans at market interest rates. This effect was particularly acute for savings and loan banks that held long-term, fixed rate mortgage on their balance sheet. Inflation was undoubtedly an important macroeconomic factor in weakening bank balance sheets across the board. However, it is unlikely to have been the sole factor. Bank profitability continued to decline and volatility rose even after interest rates and inflation stabilized in the early $1980 \mathrm{~s}^{154}$

As market shares and profits eroded in the $1980 \mathrm{~s}$, banks increased the riskiness of both their assets and liabilities. Commercial banks' share of total nonfinancial borrowing peaked around 1973 at around 35\%, but declined to just over $20 \%$ by $1990 .{ }^{155}$ The pattern for savings banks was similar over this period.

150. See Keeley, supra note 140. This measure is often used as an empirical proxy for Tobin's q, the ratio of the market value of bank assets to their replacement cost. For a history of the use of Tobin's q in different scholarly literatures, see Robert P. Bartlett \& Frank Partnoy, The Misuse of Tobin's $Q$, (U.C. Berkeley Pub. L. Res. Paper, 2018), http:/papers.ssrn.com/sol3/papers.cfm?abstract _id=3118020 [http://perma.cc/4QV8-2WHL].

151. Id.

152. See Mahoney, supra note 22 .

153. Federal Reserve Bank of St. Louis, Effective Federal Funds Rate, http:/fred.stlouisfed.org/series/FEDFUNDS [http:/perma.cc/6KZF-JXAG]. The U.S. experience with inflation in the 1960s and 1970 s cannot be separated from broader issues concerning international balance of payments and exchange rates. Michael D. Bordo \& Barry Eichengreen, Bretton Woods and the Great Inflation in THE GREAT INFLATION: THE REBIRTH OF MODERN CENTRAL BANKING (Michael D. Bordo \& Athanasios Orphanids eds., 2013).

154. See Edward \& Mishkin, supra note 148.

155. Id. 
As banks sought to replace the income lost from lending, they increased their earnings from fees, trading, and off-balance sheet activity, such as loan commitments, standby letters of credit, loan sales and securitization. Banks also increased their income from serving as dealers in the over-the-counter derivatives market. Consistent with this pattern, the share of noninterest income to total income for commercial banks rose from less than $20 \%$ in the early $1970 \mathrm{~s}$ to almost $35 \%$ by the early 1990 s. $^{156}$

Banks' loss of market share in the overall lending market took place despite the fact that loans grew as a percentage of bank assets. This relative growth in loans on banks' balance sheets occurred at the expense of safer assets such as securities, cash, and reserves. There was also a shift in the composition of bank lending. Banks' share in commercial and industrial (C\&I) loans fell as a result of competition from the commercial paper market and from foreign lenders, who targeted the largest and safest nonfinancial borrowers. Banks increased their share of mortgage loans and, within this category, increased their share of commercial mortgages. ${ }^{157}$

This increase in real estate lending eventually culminated in the savings and loan crisis of the 1980s. Savings and loan institutions moved aggressively into commercial mortgages. The number of state-chartered savings and loan associations grew by the thousands over the course of the eighties, despite the general decline in their profitability. Commercial banks also aggressively expanded their presence in this market. ${ }^{158}$

The composition of bank liabilities also changed over this period. ${ }^{159}$ From 1960 to 1990 checkable deposits went from almost $60 \%$ of bank liabilities to less than $20 \%{ }^{160}$ This period saw the rise of short-term liabilities that paid market interest rates at a time of rising inflation. These included large time depositssuch as large certificates of deposit - and security repurchase agreements. By the 1990s, such money market instruments plus small certificates of deposit made up over half of bank liabilities. The ten largest commercial banks held almost half their liabilities as money market instruments. These liabilities involved greater competition not only with money market mutual funds, but between banks themselves. The owners of money market instruments were also much

156. Id. This fee income came with a different set of risks. Off-balance sheet activities usually involved contingent liabilities. The increase in dealer activity exposed banks to risk arising from imperfectly hedged positions in their derivatives book and from counterparty failure. See BARR ET AL., supra note 38 , at 1074 .

157. Id.

158. FDIC, The Savings and Loan Crisis and Its Relationship to Banking, in AN EXAMINATION OF THE BANKING CRISES OF THE 1980S AND EARLY 1990S, at 167 (1997).

159. For detailed accounts of the changing composition of bank activities over this time, see John H. Boyd \& Mark Gertler, U.S. Commercial Banking: Trends, Cycles and Policy (NBER WORKING PAPER No. W4404 (1993)); Allen Berger et al., The Transformation of the U.S. Banking Industry: What a Long, Strange Trip It's Been, 2 BROOKINGS PAPERS ON ECON. ACTIVITY 55 (1995); and Allen Berger et al., The Consolidation of the Financial Services Industry: Causes, Consequences, and Implications for the Future, 23 J. BANKING \& FIN. 135 (1999).

160. Boyd \& Gertler, supra note 159 , at 5. 
more likely to be institutions whose demand was much more sensitive to small changes in interest rates. Again, much of the expansion of savings and loans institutions in this period was funded through such volatile, higher interest bearing deposits. ${ }^{161}$

Most notably, there was a marked increase in bank failures. Bank failures were uncommon in the $1970 \mathrm{~s}$, averaging under two per year despite the celebrated stagflation that took place over much of this period. Failures increased to 130 per year between 1982 and 1991. In 1992, the FDIC listed over 900 banks with assets of almost $\$ 500$ billion as problem institutions. ${ }^{162}$ The savings and loan industry collapsed over the course of the 1980s and was bailed out by Congress through a slow sequence of regulatory and statutory interventions. Banks that showed the greatest volatility of equity returns in the 1980 s were also those that, in earlier periods, had the lowest charter value as measured by market to book value. ${ }^{163}$ These facts suggest a mechanism through which declines in profitability were associated with subsequent risk taking.

There were, undoubtedly, a number of changes in the economic landscape that affected bank stability in addition to the increase in competition in lending and deposit markets. The roles of inflation and the Volcker recession cannot be ignored. The deregulatory ideology of the period likely reduced the focus on examinations, particularly within the Federal Home Loan Bank Board that supervised the thrifts. The increase in competition, moreover, was itself a function of a number of distinct forces such as changes in technology, markets, and foreign entry. Nevertheless, the evidence is consistent with the idea that increases in competition played an important role in the rise of bank risk taking and instability in this period.

These events bear a striking resemblance to those of the recent financial crisis. To be sure, the bank failures of the 1980s did not result in widespread panic or disruption of financial markets. Nevertheless, the competitive dynamics that led to increased risk taking in both periods had broadly similar patterns. The buildup in risky mortgage lending prior to the recent crisis was driven by lightlyregulated mortgage lenders. ${ }^{164}$ These institutions increasingly funded themselves in wholesale capital markets as part of the securitization chain. The mortgagebacked securities created through this process were largely held by financial institutions such as banks and broker dealers, who funded the purchases through short-term debt. ${ }^{165}$ Competition played an important role in the decline of

\footnotetext{
161. FDIC, supra note 158 .

162. Boyd \& Gertler, supra note 159.

163. Tina W. Galloway et al., Banks' Changing Incentives and Opportunities for Risk Taking, 21 J. BANKING \& FIN. 509 (1997).

164. See The Mortgage Machine, in FINANCIAL CRISIS INQUIRY REPORT 102 (2011).

165. See Dwight Jaffee et al, Mortgage Origination and Securitization in the Financial

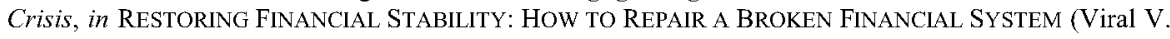
Acharya \& Matthew Richardson eds., 2009).
} 
underwriting standards at both traditional commercial banks and thrifts. ${ }^{166}$ Eventually, the government-sponsored entities Fannie Mae and Freddie Mac also accumulated large holdings of riskier mortgage loans. This competition in on the asset side of the balance sheet took place in lock step with competition on the liability side, as institutional investors in short-term debt aggressively pursued higher yields. ${ }^{167}$ Unlike the savings and loan crisis of the 1980 s which was concentrated in commercial banks and thrifts, the recent financial crisis took place across a broader set of financial institutions, including broker dealers and money market funds. However, in both periods the interaction between competition, regulation, lending risk, and funding risk played an important, and perhaps central, role.

It is ultimately beyond the scope of this Article, or any other single paper, to comprehensively assess the role of competition in the recent financial crisis. The goal is to instead highlight the evidence from U.S. banking history which suggests that limits on competition played an important role in preventing the competitive escalation of risky practices that can give rise to large-scale crises.

That said, evidence on the role of competition and financial stability is not limited to the United States. Single-country case studies and cross-country statistical evidence can both be interpreted to be consistent with this claim. Higher market concentration of banks is usually associated with a lower likelihood of major banking crises, though this relationship varies substantially with other features of the regulatory environment. ${ }^{168}$ For this reason, country case studies are likely to be more revealing than large, cross-country regressions because patterns of financial organization and regulation are deeply historically specific and exhibit substantial path dependence. Nevertheless, it is beyond the scope of this Article to offer a comprehensive cross-country analysis of the relationship between competition and financial stability.

With this caveat, two types of cases from the comparative literature are worth highlighting. ${ }^{169}$ The first is cases where countries with relatively stable banking sectors experience an episode of heightened financial instability and crisis. Here, the experience of the Nordic countries in the 1990s provides a useful comparison. In Finland, Norway, and Sweden, financial liberalization led to

166. See Marco Di Maggio et al., Deregulation, Competition, and the Race to the Bottom, MGMT. SCI. (forthcoming 2018).

167. See Marcin Kacperczyk \& Phillip Schnabl, How Safe are Money Market Funds?, 128 Q.J. ECON. 1073 (2013).

168. See Thorsten Beck et al., Bank Concentration, Competition, and Crises, $30 \mathrm{~J}$ BANKING \& FIN. 1581 (2006) (finding a positive cross-country relationship between bank concentration and financial stability but a negative relationship between regulatory policies associated with strong state control and limits on banks); Thorsten Beck et al., Bank Competition \& Stability: Cross-Country Heterogeneity, 22 J. FIN. INTERMEDIATION 218 (2013) (finding a positive cross-country relationship between bank concentration and financial stability varies substantially with the regulatory environment).

169. In selecting case studies, I have excluded developing countries, many of them in Latin America, with histories of recurring financial crises. Argentina is a developed country whose turbulent financial history can be usefully compared with that of the United States. See Spector, supra note 28 . 
large increases in lending in what had previously been a highly regulated and conservative banking sector. While broader macroeconomic policies concerning exchange rates and capital inflows played an important role, a key mechanism through which these policies translated into lending were the relaxation of prior restraints on bank lending and the induced competition for market share between financial institutions that fed a real estate bubble. ${ }^{170}$

The second type of cases worth mentioning are of banking systems that have remained stable even against the background of considerably macroeconomic instability. Canada and Australia, for example, are frequently cited as countries that have managed to avoid major banking crises. ${ }^{171}$ The Canadian example is especially useful because of how closely its economy is integrated with that of the United States. The relative stability of Canadian banking, as compared to the United States, has endured for over one hundred and fifty years. ${ }^{172}$ The contrast between Canada and United States was remarked upon throughout the history of U.S. banking panics in the nineteenth and early twentieth centuries, most notably in the aftermath of the Panic of 1908 and the debates that led to the creation of the Federal Reserve.

Remarkably, Canada suffered no major bank failures during the Great Depression. ${ }^{173}$ This fact is especially salient given the common agricultural shocks faced by both the United States and Canada, the size of agricultural sector, and importance of trade to the Canadian economy. While the Canadian economy contracted substantially during the Depression, the comparative stability of its banking system likely resulted in smaller financial spillovers relative to the United States. ${ }^{174}$ The superior regional diversification of Canadian banks, again relative to the fragmented U.S. structure, is an important factor in this difference. However, there is also evidence that the greater concentration of the Canadian banking sector also enhanced stability in other ways. In particular, banks had incentives to coordinate their activity and offer conditional support to one another in the event of a common shock. This need for coordination also affected bank incentives to accept common regulatory restrictions that would limit the liability that large banks could place on each other. These incentives are

170. Lars Jonung, Twelve Lessons from the Nordic Experience of Financial Liberalization, in THE GREAT FINANCIAL CRISIS IN FINLAND AND SWEDEN: THE NORDIC EXPERIENCE OF FinANCIAL LIBERALIZATION 301 (Lars Jonung et al. eds., 2009); Seppo Honkapohja, Financial Crises: Lessons from the Nordic Experience, 13 J. FIN. STABILITY 193 (2014),

171. See, e.g., Gordon Isfeld, Canada's Banks Shake Off Global Sector Crisis, FIN. POST (Oct. 10, 2012) http:/business.financialpost.com/news/fp-street/canadas-banks-shake-off-globalsector-crisis [http:/perma.cc/QJN9-2BLD]; Phil Dobbie, How Australia Ducked the Crisis, MONEYWATCH (Oct. 14, 2009, 3:00 AM), http:/www.cbsnews.com/news/how-australia-ducked-thecrisis/ [http:/perma.cc/2E2P-5XS3].

172. Michael D. Bordo et al., Why Didn't Canada Have a Banking Crisis in 2008 (or in 1930, or 1907, or . . .)?, 68 ECON. HIST. REV. 218 (2014).

173. Barry Eichengreen \& Kris Mitchener, The Great Depression as a Credit Boom Gone Wrong (Bank of Int'1 Settlements Working Paper No. 137, 2003).

174. Joseph G. Haubrich, Nonmonetary Effects of Financial Crises: Lessons from the Great Depression in Canada, 25 J. MONETARY ECON. 223 (1990). 
consistent with the much greater limits placed on Canadian banks to lend against real estate. ${ }^{175}$ There is also related evidence that the more concentrated structure of Canadian banking better facilitated implicit and explicit government support. $^{176}$

Finally, Canadian banks weathered the recent financial crisis far better than their U.S. counterparts. ${ }^{177}$ The key difference this time was less reliance on wholesale sources of funding as opposed to deposits. This difference suggests both a lower willingness and ability on the part of Canadian banks to rapidly expand bank balance sheets through volatile sources of funding. Taken together, both domestic and comparative evidence are consistent with the view that increases in bank competition can result in excessive instability.

\section{B. Public Choice on its Head}

This body of theory and evidence suggests that we rethink the role of restraints on competition in maintaining financial stability. The best way to conceptualize this role is, ironically, to turn the public choice critique of regulation on its head. Competitive restrictions in banking facilitated a banking cartel. For each problem in the creation and maintenance of a cartel, these restrictions offered a distinct legal, political, and economic solution. Recall the cartel problems of establishing agreement, detecting deviations from that agreement, and credibly punishing the deviations. The agreement was embedded in federal statutes and rules. Detection by either private or public parties was likely to lead to enforcement. Enforcement took place through both public action - formal and informal and private litigation.

In the absence of regulation, it is unlikely that the banking industry would be able to maintain a cartel on anywhere near this scale. The impediments to successful coordination would be high, even in the absence of antitrust and other laws preventing explicit agreements. Regulation facilitated such coordination, creating industry rents through controls on price, product, entry, and location. These controls included deposit insurance, interest rate ceilings on deposits, charter provisions, branching restrictions, and the separation of banking and investment banking. In the case of deposits, for example, the evidence suggests that banks would be unable to exercise significant market power in the absence of facilitating regulation. The oligopoly problems of agreement and punishment would be too difficult to solve. The agreements that regulation was able to coordinate through the Interest Rate Adjustment Act of 1966 were complex. In the absence of public regulatory authority they would likely unravel. This is illustrated by the historical example of NOW accounts. However, once these

175. Eichengreen \& Mitchener, supra note 173 .

176. Lawrence Kryzanowski \& Gordon S. Roberts, Canadian Banking Insolvency, 1922-1940, 25 J. MONEY, CREDIT \& BANKING 361 (1993).

177. Lev Ratnovski \& Rocco Huang, Why Are Canadian Banks More Resilient? (IMF Working Paper No. 152, 2009). 
regulatory agreements were in place, banks were able and willing to inform regulators of actions by competitors that threatened their cartel profits.

The rules and standards adopted were particularly suited to cartel maintenance. Both oligopoly theory and empirical studies of actual cartels suggest that detailed, ex ante agreements may be crucial for cartel stability. ${ }^{178}$ Defining the content of the agreement ex ante is also necessary to give industry members the incentives to monitor the agreement and detect any deviations by incumbents or entrants. Consistent with this insight, regulation utilized ex ante rules to provide content to the restrictions that created rents for the industry. For example, the Banking Act of 1933 prohibited the payment of interest "directly or indirectly by any device whatsoever" on "any deposit which is payable by demand." $" 179$

While the content of the agreement on deposit interest rates pay no interest - was defined through ex ante rules, the scope of the agreement was defined through an ex post standard. ${ }^{180}$ The scope of the agreement required defining a number of terms, such as "interest," "deposit," and "bank." These are exactly the dimensions on which deviations from the price agreement were likely to occur. The use of an ex post standard allowed the scope of the rule to expand as new forms of substitutes emerged to take advantage of the profitable opportunities created by the restrictions. If banks brought these substitutes to the regulator's attention or if they were discovered in the examination process, the regulator had the authority to prevent them. The use of standards also allowed regulators to prevent entry from institutions that were outside the current scope of regulatory authority. Neither regulators nor industry participants would have been able to anticipate all possible forms of deviation from the agreement and cover them exhaustively as rules in the regulation. Standards allowed new information that arose after the passage of the law or regulation to inform enforcement.

To illustrate, it would be difficult to find a better example of broad regulatory authority to define deposits than the National Bank Act of 1935, which established a prohibition on deposit interest for FDIC-insured banks. The 1935 Act defines "deposits" to include those "obligations of a bank as the (FDIC's) board of directors shall find and shall prescribe by its regulations to be deposit liabilities by general usage." The perfect circularity of this definition allowed regulators to determine ex post whether any particular commercial

178. See generally ROBERT C. MARSHALL \& LESLIE MARX, THE ECONOMICS OF COLLUSION: CARTELS AND BIDDING RINGS (2014) (describing the theoretical basis and empirical evidence for detailed agreements in different cartel settings).

179. Banking Act of 1933, Pub. L. No. 73-66, 48 Stat. 162 (1933).

180. Louis Kaplow, Rules Versus Standards, 42 DUKE L.J. 557 (1992). In Kaplow's framework, the difference between rules and standards is distinct from their complexity. Complexity refers to the number and difficulty of the distinctions that a rule or standard makes. For every simple or complex rule, there is at least in principle an equivalent (de facto) simple or complex standard. The converse is also true. See Louis Kaplow, A Model of the Optimal Complexity of Legal Rules, 11 J.L. ECON. \& ORG. 150 (1995). 
practice could have the effect of undermining the cartel profits that were built on bank control of the deposit market.

Undoubtedly, these restrictions had a number of negative consequences for both efficiency and distribution. For example, low deposit rates may have distorted household savings decisions and likely resulted in a regressive transfer of wealth from small depositors to bank equity holders. However, an important caveat is that the most intractable market failures - at least in banking are quite distinct from that of price distortions through collective market power. As described in Part $\mathbf{I}$, these market failures are instead a result of the externalities associated with the financial structure of banks. Theory and evidence suggest that both market forces and public insurance create incentives for bank owners and managers to take excessive risks, from a social point of view, on both the asset and liability sides of the balance sheet. ${ }^{181}$ What is perhaps less appreciated is that regulators face many of the same limitations as market participants in monitoring and deterring excessive risk taking by banks. These limitations place a premium on regulatory tools that can limit bank risk taking without requiring direct observation of bank risk.

Regulations that increase bank charter value are one such tool. Crucially, they have the additional advantage that they can lower bank risk without requiring regulators to directly observe and prevent it. Of course, the competitive restrictions in New Deal regulation also created and maintained bank charter value through regulatory-created market power. But few regulations exist that do not also create costs along other dimensions. Regardless of whether this system struck an appropriate balance between the benefits of risk reduction against the costs of market power, it is important to recognize that such a tradeoff exists and may be, at least in principle, a useful tool in the arsenal of contemporary bank regulation. In at least this limited sense, the design - if not the details of the New Deal banking system is instructive.

It is also worth distinguishing when it may be appropriate to view regulation-created rents as at least partly virtuous, rather than wholly vicious. Public choice critics of regulation largely focused their attention on industries in the transportation and telecommunication sectors, such as airlines, trucking, railroad, and telephone. These industries often featured economies of scale, barriers to entry, and oligopolistic market structures. According to these critics, regulations exacerbated the very market failure - market power - that they were designed to prevent. Far from limiting market power, regulation became a tool of the industry to establish and maintain it.

To be clear, when social costs arise principally the problem of natural monopoly - for example, industries with increasing returns to scale that arise from technology or network effects regulation should be relatively more concerned with limiting the ability of powerful firms to use their market power

181. See Mark J. Roe \& Michael Troege, Containing Systemic Risk by Taxing Banks Properly, 35 YALE J. ON REG. 181, 181-83 (2018). 
to collude and exclude. As public choice critics have consistently argued, in the context of natural monopoly, evidence that regulation enhances a cartel is often evidence against the social value of regulation. This contrast with banking is worth emphasizing, and may have been overlooked by public choice critics because of their focus on industries other than banking. The theory of oligopoly has seen its greatest value in introducing competition to exactly those industries e.g., transportation, telecommunications, and energy - where natural monopoly was thought to be an inescapable economic fact of life. It also informs the core antitrust principles developed to detect and deter successful cartel behavior in these same industries. However, in the context of bank regulation, I suggest that oligopoly theory may sometimes be useful for creating a legal, political, and economic architecture that facilitates, rather than frustrates, cartels. I leave the possible application of this argument to other industries to future work.

\section{Bank Regulation in the Shadow of Capital Markets}

This Article has tried to describe how bestowing rents on banks helped to create: (1) controls on risk taking and (2) limits on regulatory arbitrage. A wholesale return to these past methods is neither feasible nor desirable. Banking and financial markets have evolved, and statutorily-mandated price limits are disfavored as a regulatory method. Nevertheless, it can be instructive to examine past solutions, however imperfect, because risk and arbitrage continue to be two of the central themes of bank regulation. In this Part, I outline a legal, political, and economic (LPE) model that attempts to apply some of these insights from the past to contemporary institutions and practices. I also identify some of the major challenges that would be associated with this model. The principle behind the model is straightforward. Banks should be allowed to issue comparatively safe liabilities and be required to hold comparatively assets. In return, bank should be able to adopt, within limits, liability structures that by their nature create some systemic risk. Nonbanks should be required to offer issue liabilities that pose little systemic risk and, in return, be allowed free rein to invest in assets.

How could such a model be put into practice? Capital, liquidity, and maturity requirements could be set at much higher levels for existing, large bank holding companies. ${ }^{182}$ For example, regulation could target future aggregate levels of capital of thirty percent and medium-to-long-term subordinated debt of an additional thirty percent across all bank holding companies. ${ }^{183}$ Similar

182. Small to medium-sized banks that are funded mostly by retail deposits would be exempted. The size threshold for any particular institution is less important than the requirement that, in the aggregate, these regulations cover most of the assets that are not funded through insured, retail deposits. To facilitate coordination, it would also be important that the overall industry structure remain largely oligopolistic.

183. Note that specifying such targets is distinct from the specifying the time by which bank holding companies should attain these targets. 
requirements could exist for bank liquidity and maturity. In principle, this corresponds to increasing the tax associated with highly leveraged, illiquid, and maturity mismatched financial institutions. With such requirements in place, it would take a much more substantial fall in asset values to threaten the stability of the banking system. As a result, regulators' margin of error in assessing bank risk would be much lower under this regime than under one of highly-leveraged banks issuing wholesale, short-term debt to finance illiquid or potentially illiquid assets. $^{184}$

Of course, imposing onerous funding requirements on the largest bank holding companies would create a competitive advantage for financial intermediaries that are not subject to such requirements. Substantial amounts of banking activity - defined as financial intermediation near the market's endpoint on the continuum of credit, maturity, and liquidity transformation - would eventually move outside of bank holding companies. This is arbitrage outside the regulated banking system. While such arbitrage opportunities are a natural concomitant of any system of regulation, a heavy effective tax on aggregate leverage among financial holding companies would require a more comprehensive regulatory approach to this issue than is currently the case. ${ }^{185}$ Such a change in regulatory emphasis may be welcome. It may be easier for regulators to identify the migration of banking activity outside the regulatory perimeter than to track subtle changes in the risk profile of highly-leveraged and maturity-mismatched banks. Even when it is not, as explained below, it will be in the interest of at least some regulated financial institutions to help inform regulators of this migration.

Preventing arbitrage outside the regulatory perimeter requires, at a minimum, that regulators be able to identify nonbanks that adopt liability structures that are similar to banks. Here, existing bank regulation provides many of the conceptual tools required for such an analysis. The same metrics that are used to measure capital, liquidity, and maturity can be used to gauge whether a nonbank poses similar risks to the existing set of banks. This is a comparative exercise because it does not require a regulator to measure the level of risk accurately. It would instead prevent nonbanks from being comparably risky on the same measures. As a result, it would limit competition from nonbanks on this, potentially pernicious dimension. Again, the capital, maturity, and liquidity requirements for the largest bank holding companies can be set high enough to ensure a large margin of error in this process.

To take a simple example, it is not difficult to determine that a special purpose vehicle (SPV) that holds residential mortgages and issues short-term

184. In principle, regulation could also specify standardized, underwriting requirements for bank assets along the lines of what the Government Sponsored Entities (GSEs) have done for conformable mortgages. Government agencies are eminently capable of producing such standards.

185. For a related proposal, see Roe \& Troege, supra note 181. 
commercial paper is functionally engaged in banking. ${ }^{186} \mathrm{~A}$ real estate downturn could easily trigger a run of redemptions against all such SPVs. ${ }^{187}$ Measuring the risk-weighted capital, liquidity coverage, and stable funding of an SPV under Basel III would be no more or less complicated than examining the real estate book of a bank. The composition of the SPV's assets - mortgages - and, by inference, their likely correlation with the fate of mortgages held by banks in the event of a downturn would be sufficient to establish the required similarity. Focusing on the securitization structure also avoids having to distinguish between different owners of securities. In this example, the SPV would be classified as engaged in banking activity regardless of the investment vehicle that ultimately held the commercial paper-for example, a money-market mutual fund, a short-term bond fund, or any other type of mutual, exchange-traded, or pension fund. ${ }^{188}$

The task of regulation would be to ensure that nonbanks, once identified, could not operate with financial structures that allowed themselves to be funded on more favorable terms than banks. In other words, a nonbank that held financial assets should have at least as much capital, liquidity, and/or maturity as a bank. In our securitization example, if an SPV funded itself by issuing bonds then those bonds would need to have at least as long a weighted-average maturity - preferably, much longer - than would be required of a bank. Bondholders would also have limited rights to force asset sales by the SPV in the event of nonpayment of interest. They would still have the ability to buy and sell bonds and enter into interest rate swaps with other market participants. ${ }^{189}$ These market features would place a floor on any aggregate inefficiency that might result from the liquidity premium that investors would have to pay.

Preventing regulatory arbitrage outside the banking system would require a federal regulator - for example, the Federal Reserve - to have broad legal authority to extend bank-like regulation to nonbank institutions and activities. The regulator's goal would be to ensure that nonbank financial institutions that may compete with banks on the asset side of the balance sheet have liability structures that are considerably safer than banks. Nonbank institutions found to

186. Special purpose vehicles are bankruptcy-remote legal vehicles used to hold asset backed securities. Steven L. Schwarcz, The Alchemy of Asset Securitization, 1 STAN. J.L. BUS. \& FIN. 133 (1994)

187. The risk that redemptions outside regulated banks could destabilize the financial system does not turn on the size of any single SPV, but instead on the aggregate size of SPVs and their linkages to the regulated banking system. supra note 28 .

188. For an approach that would likely directly regulate such institutions, see RICKS,

189. To make the model work, financial intermediaries in the derivative markets should not be able to accumulate large, one-sided derivative positions. I thank Roberto Romano for bringing this point to my attention. Existing derivative regulation is already moving in this direction. For sophisticated analyses of derivative regulation in the Dodd-Frank Act, see Yesha Yadav, The Problematic Case of Clearinghouses in Complex Markets, GEO. L.J. 2013, Mark J. Roe, Clearinghouse Overconfidence, 101 CALIF. L. REv. 1641 (2013), and Adam Levitin, Response: The Tenuous Case for Derivatives Clearinghouses, 101 GEO. L.J. 445 (2013). 
pose these risks would be faced with the choice of funding themselves in a less risky manner or to register as a bank holding company. This requires supplementing the stringent capital, liquidity, and maturity requirements on banks with even more stringent prohibitions on nonbank liabilities. In turn, nonbanks would have much greater freedom with respect to the assets they hold. These prohibitions could take the form of guidelines to nonbanks on how to structure themselves to avoid registering as a bank holding company. It would also require nonbanks to periodically disclose their financial structure to the regulator and be subject to examination. Some institutions, such as securitization vehicles, would by their nature be required to disclose, while the regulator could retain broad power to request disclosures from other non-bank financial institutions.

The legal, political, and economic structure of this regulatory model is similar in a number of ways to the restrictions on competition that were once a common in banking. First, the model creates a system of legal privileges and prohibitions that govern the issuance of panic-prone debt. ${ }^{190}$ Banking regulation does so explicitly in the case of deposits. Banks have the exclusive legal privilege of offering deposits. The analogy between deposits and panic-prone debt suggests a legal framework for the latter that is also two-tiered, but not quite so dichotomous. ${ }^{191}$ Banks would have the privilege of being able to operate with larger proportions of short-term, demandable debt than other financial institutions holding comparable assets. Of course, banks are already subject to a large set of regulatory prohibitions. Most importantly, they must maintain minimum amounts of capital, liquidity, and maturity for their liabilities. The key to turning these prohibitions into (relative) privileges is to subject competing nonbanks to even more stringent regulation along each of these three dimensions.

Second, it makes use of ex ante rules and ex post standards to define the scope of privileged and prohibited bank activities. Capital, liquidity, and maturity requirements would be defined ex ante through administrative rulemaking. The only difference is that they would be set at high enough levels so as to shrink the banking sector. ${ }^{192}$ Panic-prone debt would be defined through an ex post standard. This standard must be flexible enough to adjust to innovations that create the opportunity for regulatory arbitrage. It would not, however, be unprincipled or unpredictable because it would be anchored in the same regulatory measures used to regulate banks. The qualitative and

190. Id.

191. For a stimulating account of the dangers of regulation that can lead to excessive herding and thereby create unintended system risk, see Ian Ayres \& Joshua Mitts, Anti-Herding Regulation, 5 HARV. BUS. L. REV. 1 (2015). For the usefulness of regulation-induced herding to economic analysis, see Henrik Jacobsen Kleven, Bunching, 8 ANN. REV. ECON. 435 (2016). This approach was pioneered in Emmanuel Saez, Do Taypayers Bunch at Kink Points?, 2 AM. ECON. J.: ECON. POLICY 180 (2010).

192. I thank Mark Perlow for the useful reminder that U.S. bank regulators often wish to expand the size of the banking sector relative to the capital markets that are under the purview of the SEC or the CFTC. 
quantitative definitions that apply to capital, liquidity, and maturity requirements for bank holding companies would form the basis for deciding whether the financial structure of nonbank competitors, either individually or in the aggregate, posed any systemic risk.

Third, it creates a rent for banks that have the privilege of issuing panicprone debt in appreciable quantities. This rent arises because limiting the aggregate quantity of such debt raises its price and, equivalently, lowers its yield. ${ }^{193}$ A shortage of such debt, relative to the socially excessive amount demanded by the market, then results in lower funding costs for institutions that can issue it in larger proportions. An aggregate limit on debt is analogous to the explicit price controls on deposits that existed by statute. This quantity limit would not only help correct the externality from the mispricing of panic-prone debt, it would have the additional benefit of limiting bank incentives to take risk without relying on regulators to precisely observe the risk. This regulatory model would induce beneficial risk reduction within banks, over and above what can be achieved through standardized underwriting, as a byproduct of its approach to regulatory arbitrage.

Fourth and finally, this model enlists banks in regulatory enforcement. Bank have a vested stake in any system that prevents competitors from taking advantage of the capital, liquidity, and maturity requirements imposed on them. As a result, they would have strong incentives to inform regulators and persuade them to take action against nonbank competitors whose financial structures indicated comparable levels of credit, liquidity, and maturity mismatch. Regulators could develop a formal complaint procedure for banks to raise concerns about regulatory arbitrage both outside and even within the regulated banking sector, which would result in a cease and desist order. This mechanism could be combined with private rights of action. Returning to our securitization example, banks would be eager to inform regulators of the growth of securitization vehicles that held similar assets but could be funded with greater leverage and shorter maturity.

A final advantage of this model is that while its philosophy and key regulatory parameters for capital, liquidity, and maturity may represent a departure from existing regulation, its institutional structure does not. In fact, the Dodd-Frank Act provides much of the regulatory architecture to implement the model's goals of enhancing social stability. It does so in two principle ways. First, the Dodd-Frank Act mandates enhanced prudential standards for the largest bank holding companies. ${ }^{194}$ These include capital, liquidity, and maturity

193. See Jeremy C. Stein, Monetary Policy as Financial-Stability Regulation, 127 Q.J. ECON. 57 (2012) (developing a model in which monetary policy can effectively capping the amount of short-term money creation); Robin Greenwood et al., The Federal Reserve's Balance Sheet as a Financial-Stability Tool, in JACKSON HOLE ECONOMIC SYMPOSIUM CONFERENCE PROCEEDINGS 335 (2016) (arguing that monetary policy can enhance financial stability by increasing the slope of the shortterm end of the yield curve and thereby crowd out private money creation).

194. Dodd-Frank Act $\$ 165$ (codified at 12 U.S.C. $\$ 5365$ (2018)). 
requirements as well as a regime of supervisory and bank-run stress tests to determine whether banks will be able to conform to these requirements in adverse financial and economic conditions. ${ }^{195}$ Second, the Dodd-Frank Act provides a regulatory process for the FSOC to designate nonbank financial institutions as systemically important. ${ }^{196}$

Despite these similarities, the Dodd-Frank Act still falls short of implementing the model described in this Part. For all the thousands of pages of regulatory text devoted to specifying enhanced prudential standards, the largest, most complex banks still qualify as adequately capitalized if they maintain a leverage ratio of just four percent of common equity relative to average total assets. ${ }^{197}$ As a result, the Dodd-Frank Act has not done enough to shrink the size of banks relative to sources of long-term financing in the capital markets. Banks appear to be much less leveraged when using regulatory measures that attempt to assess the riskiness of a bank's assets. ${ }^{198}$ However, for any regulatory measure of leverage that constrains a bank - whether risk adjusted or not — banks have incentives to increase their asset risk in ways that are not observable to regulators. If the past is any guide to the present, then banks currently have much higher levels of risk than are measured through regulatory risk weights. This mismatch between actual and measured risk is likely to increase over time as banks better learn how to game the system. Arbitrage can occur both inside and outside the regulated banking system.

The Dodd-Frank Act is particularly vulnerable to this kind of arbitrage. Preventing it requires regulators to assess the aggregate risks imposed by large and complex banks. This task, which is daunting enough on its own, is even more challenging for the highly-leveraged, maturity-mismatched banks permitted by the Dodd-Frank Act. At high levels of leverage, it is difficult for regulators to gauge the many ways that banks can amplify their return on equity using seemingly low risk assets. High leverage also implies that regulators have a thin margin of error, so that small lapses in oversight can result in inefficiently large tail or systemic risks. By continuing to allow bank holding companies to operate in this manner, Dodd-Frank Act sets federal regulators a difficult, perhaps impossible, task.

The designation process created through the Dodd-Frank Act also suffers from a number of weaknesses. ${ }^{199}$ The FSOC is too fragmented in its decisionmaking authority to permit a consistent and principled approach to designating institutions on the basis of their aggregate activity. So far, the designation

\footnotetext{
195. Id.

196. Id. $\S 113$ (codified at 12 U.S.C. $\$ 5323$ ).

197. 12 C.F.R. $\$ 3.10$ (2017)

198. Press Release, Fed. Res. Bd., Federal Reserve Board Releases Results of Supervisory Bank Stress Tests (June 22, 2017), http:/www.federalreserve.gov/new sevents/pressreleases bcreg20170622a.htm [http://perma.cc/KP7K-GC7T].

67.

199. For a comprehensive analysis of this process, see Schwarcz \& Zaring, supra note
} 
process for nonbank financial institutions has not adequately focused on preventing arbitrage outside the regulated banking system. ${ }^{200}$ This is in part because current prudential regulation has not been stringent enough to move this activity outside banks. Under the model described above, the goal of prudential regulation is to shrink the banking system relative to the capital markets and to prevent the capital markets from recreating the same run risks that are found in banking. In contrast, in the aftermath of the financial crisis, the largest bank holding companies have grown larger. ${ }^{201}$ There are undoubtedly a number of legal, political, and policy questions embedded in the designation process. Here, I limit myself to a few observations that are most directly relevant to the themes developed in this Article.

With the exception of clearinghouses and other financial market utilities, the FSOC has focused on individual institutions rather than aggregate markets. ${ }^{202}$ The FSOC did so even under the Obama Administration despite the fact that the statutory language for its power to designate is broad, ${ }^{203}$ as is the language of the FSOC's implementing regulations. ${ }^{204}$ The FSOC's focus on individual institutions overlooks the fact that the aggregate or systemic implications of many small entities engaging in regulatory arbitrage outside of the bank holding company structure can be profound. Looking only to the size, complexity, or interconnectedness of particular financial institutions can miss this mark. ${ }^{205}$ It is more important to regulate the financial structure of the many securitization vehicles creating the bonds that are bought by the largest insurance companies or assets managers than it is to focus on the latter. For example, some forms of regulation on asset managers, such as requiring money market funds to hold more liquid and hence shorter-term assets can do more harm than good. ${ }^{206}$

200. To date, designation has largely focused on insurance companies. See Financial Stability Oversight Council Designations, U.S. DEP'T TREASURY, http://www.treasury.gov/initiatives /fsoc/designations/Pages/default.aspx\#nonbank [http:/perma.cc/V9PJ-SVS3].

201. Matt Egan, Too-Big-to-Fail Banks Keep Getting Bigger, CNN MONEY (Nov. 21, 2017, 3:43 PM), http://money.cnn.com/2017/11/21/investing/banks-too-big-to-fail-jpmorgan-bank-ofamerica/index.html [http:/perma.cc/MFQ4-NVU9].

202. Financial Stability Oversight Council Designations, supra note 200.

203. Dodd-Frank Act $\$ 113$ (codified at 12 U.S.C. $\$ 5323(2018)$ ).

204. 12 C.F.R. $\$ 1310.11(2017)$

205. This is not to suggest, for example, that the Federal Reserve should not have better access to proprietary data on the risks posed by large insurers. The experience of AIG during the financial crisis shows that derivative trading can leave large banks exposed to the counterparty risk from the failure of a large insurer. Those risks are important for bank regulators to understand, but they nevertheless originated ultimately from mortgage risk on bank balance sheets that were hedged using derivatives. For further analysis of the designation of insurance companies, see Schwarcz \& Zaring, supra note 67.

206. Non-government money market funds overwhelmingly hold debt that is issued by banks. The net effect of such liquidity requirements for funds may well be to shorten the maturity of bank debt. In 2012 for example the top fifty global banks accounted for about ninety percent of money market fund assets that were not explicitly backed by the government. Perspectives on Money Market Mutual Fund Reforms: Before the S. Comm. on Banking, Housing, \& Urb. Aff., 112th Cong. 126 (2012) (statement of David S. Scharfstein, Professor, Harv. Bus. Sch.). Again, this is not to suggest that a regulator like the Federal Reserve with a mandate to limit systemic risk should not seek information from such funds. Such 
The FSOC's approach has, to date, not designated any entity that could be labeled a competitor of banks engaging in what $I$ have called arbitrage outside the system. ${ }^{207}$ One reason is the focus on individual institutions mentioned above. Just as important, however, are the relatively weak capital, liquidity, and maturity limits established by the Dodd-Frank Act. These requirements were not strong enough to prompt any substantial outflow of activity from the regulated banking system. For example, the current outstanding volume of asset-backedcommercial paper (ABCP) stands at a little over $\$ 200$ billion. ${ }^{208}$ This is one third of the volume outstanding in 2001, when the Federal Reserve first started to track this aggregate. ${ }^{209}$ There are of course a number of reasons behind the decline in securitization activity in aftermath of the financial crisis, but it is noteworthy how little recovery there has been in this market despite the overall recovery of stock and other asset prices. It is therefore reasonable to conclude that if bank capital, liquidity, and maturity regulation were much more stringent, it would eventually push more financial intermediation into the capital markets through securitization. $\mathrm{ABCP}$ would be an obvious form of arbitrage around prudential regulation. The task of designation should be to regulate $\mathrm{ABCP}$ structures to prevent this from taking place. Currently, the most salient regulatory barrier to greater securitization activity are the Dodd-Frank's risk retention requirements, which are best understood as a weak constraint. ${ }^{210}$

To summarize, the Dodd-Frank Act does not go far enough in its capital, liquidity and maturity requirements for bank holding companies, and it has not adopted a coherent framework to force financial intermediation into the capital markets while preventing the migration of banking risks outside the regulated banking system. The legal, political, and economic model outlined above would push the Dodd-Frank Act forward on each of these dimensions. It does, however, raise a number of important concerns. Here, I highlight some of the major objections to implementing such a model. I first consider whether the model would have negative consequences for financial intermediation and investment. I then consider whether it would be feasible to implement. Both of these concerns are valid, and no defense of this model can fully allay them. But this is true for any particular model of financial regulation. I reserve a full articulation the model outlined here and its inevitably partial defense to future work.

requests could be an important channel through which the regulator learns of fund investments in securitization or other vehicles that are essentially operating like banks

207. Insurance companies do not fall under this definition to the extent that their sources of funding are relatively stable.

208. Asset-Backed Commercial Paper Outstanding, FED. RES. BANK ST. LOUIS (Mar. 15, 2018), http:/fred.stlouisfed.org/series/ABCOMP [http:/perma.cc/JSQ8-D7CH]. When the underlying assets are mortgages, asset-backed commercial paper represents an extreme form of maturity transformation because the maturity of the commercial paper is typically between ninety and one hundred and eighty days.

209. Id.

210. Ryan Bubb \& Prasad Krishnamurthy, Regulating Against Bubbles, 163 U. PA. L.

REV. 1539 (2015). 
A fundamental objection to this model is that the capital, liquidity, and maturity requirements proposed for banks and, in addition, for nonbank competitors would be too severe. It can be argued that such requirements would cripple financial intermediation and, as a result, curtail economic output and growth. However, as I and others have suggested elsewhere, these concerns are overblown in the context of banking activity that could and does readily take place through long-term, stable sources of funding in the capital markets. ${ }^{211}$ Put simply, banks are just one set of institutions that conduct financial intermediation. This objection also loses much of its force when these requirements are phased in gradually and predictably over a number of years. ${ }^{212}$

In fact, these requirements may spur socially valuable innovation. ${ }^{213}$ Historically, limitations on U.S. banks may have played an important role in the growth and deepening of U.S. capital markets. ${ }^{214}$ In what directions might innovation take place today? It is possible that the current demand for liquid, short-term financial claims by household and institutions is as much a function of path dependence and outmoded institutions as it is of real demands for liquidity. ${ }^{215}$ For the wealthy households that hold most of the aggregate financial wealth in the economy, there is no need to have any assets in transaction accounts. ${ }^{216}$ A single financial account with the household's optimal portfolio could readily act as both an investment vehicle and source of liquidity to make payments. That portfolio would be constructed with an eye to risk as opposed to liquidity because most financial securities can be readily sold. A number of companies already offer services that come close to this description. ${ }^{217}$ Moreover, for the non-financial firms that account for a large fraction of moneylike, short-term financial instruments, these holdings may not be in their

211. ANAT AdMati \& Martin Hellwig, The BanKer's New Clothes: What's WRONG WITH BANKING AND WHAT TO DO ABOUT IT (2014); Anat Admati et al, Fallacies and Irrelevant Facts in the Discussion of Capital Regulation, in CENTRAL BANKING AT A CROSSROADS: EUROPE AND BEYOND 33 (Charles Goodhart ed., 2014); Prasad Krishnamurthy, Regulating Capital, 4 HARV. BUS. L. REV. 1 (2014); John H. Cochrane, Equity-Financed Banking and a Run-Free Financial System, Address at Ending Too Big to Fail: Federal Reserve Bank of Minnesota Symposium (May 16, 2016), $\mathrm{http}: / /$ faculty.chicagobooth.edu/john.cochrane/research/papers/run-free_talk_mn_2016.pdf [http:/perma.cc/T3WV-QSTY].

212. Krishnamurthy, supra note 211.

213. For a general account of how regulation can foster innovation, see Paul Joskow \& Nancy Rose, The Effects of Economic Regulation, in HANDBOOK OF INDUSTRIAL ORGANIZATION (R. Schmalensee and R.D. Willig ed., 1989). For a more critical perspective of the role that regulation should and should not play in financial innovation, see Kathryn Judge, Investor-Driven Financial Innovation, HARV. BUS. L. REV. (forthcoming 2018); and E. Glen Weyl \& Eric Posner, An FDA for Financial Innovation: Applying the Insurable Interest Doctrine to 21 st Century Financial Markets, $107 \mathrm{NW}$. L. REV. 1307 (2013).

214. See Franklin Allen \& Douglas Gale, Comparing Financial Systems (2001) (describing how market-based financial intermediation became more dominant in the United States and United Kingdom relative to Germany and Japan).

215. Cochrane, supra note 211; John Cochrane, Finance: Function Matters Not Size, 27 J. ECON. PERSP. 29 (2013).

216. See id.

217. These include companies like Wealthfront and Betterment. 
shareholders' interest. After all, if the cash was returned to shareholders it would not be reinvested in such low-risk securities. As a result, current levels of institutional cash holding may represent an agency cost as opposed to socially optimal liquidity levels for investment and payment purposes.

For these reasons, it may be that much of the inherent run risk in the current financial structure of banks is actually unnecessary. Financial deepening and innovation could make this even more true over time. In light of this possibility, it is not surprising that the banking industry would cling to the benefits of an outmoded model. A central assumption of the model of regulation outlined here is that the regulated banking sector is currently too large and should shrink even more as a fraction of the financial sector over time. There is no way to demonstrate this convincingly to a confirmed skeptic, but debates over regulation at this scale are more adequately described by burden shifting than by standards of proof. The case against the existing size and organization of the banking system is strong enough, both in my view and that of more seasoned observers, to shift the burden of proof to the banking industry.

Of course, even if it is conceded that such a legal, political, and economic model of regulation would be desirable, there are a number of challenges that it would face in its implementation. First, regulators would need to determine appropriate levels of capital, liquidity, and maturity requirements for bank holding companies and, perhaps more importantly, the transition path to achieving these levels. It would be disruptive to require bank holding companies to make dramatic changes to their liability structure in a short period of time. It would instead be more feasible to mandate a transition path over a decade or more. Specifying a set of gradual, mandatory increases on each of these dimensions makes the calculation of an ultimate level less important.

Second, regulators would need to issue guidance for nonbank competitors of banks to ensure that they operated with levels of capital, liquidity, and maturity that were substantially higher than those permitted for banks. This guidance would need to enable institutions to organize their finances while preserving regulatory flexibility to deal with innovative practices. Specifying new targets and a transition path for already existing regulatory requirements does not require much in the way of regulatory innovation relative to the current, Basel-based system. Nevertheless, extending bank regulation beyond bank holding companies would continuously raise issues concerning the application of these Basel concepts to new forms of financial organization. But regulators must eventually face these issues anyway, and they are not insurmountable. Moreover, there can be considerable margin for error in this process of quasidesignation, unlike the process of accurately assessing the risks of highly-levered financial institutions. The relationship between the risks of banking panics and the volume of credit, maturity, and liquidity mismatch in nonbank financial institutions is highly nonlinear. The risk only becomes appreciable at sufficient 
scale. ${ }^{218}$ As a result, regulators need only an approximate understanding of the effective size of the banking system. It is therefore reasonable to conclude that the political challenges of implementation exceed their purely technocratic ones.

That said, the political challenges to implementation would be formidable, and are unlikely to be overcome until or unless a new financial crisis emerges that reveals the weakness of the existing regulatory structure. ${ }^{219}$ Even in the latter case the political obstacles would remain. Bank holding companies have already adjusted to the Dodd-Frank regime of prudential regulation and stress testing. They are already starting to make inroads on relaxing leverage requirements, and they would vigorously oppose any increase in other capital, liquidity, or maturity requirements. ${ }^{20}$ Similarly, the extension of Federal Reserve oversight to nonbank financial companies has been vigorously contested in the courts. ${ }^{221}$ The FSOC is unlikely to clarify its authority in this area because the political capital for further expansion of the regulatory umbrella has been spent. ${ }^{222}$ That capital account is better described as in arrears than surplus. Currently, there is no prospect that SIFI designation will be extended to the asset management industry. Even in a different political environment, the asset management industry's natural regulatory ally would be the SEC. Regardless of party control, the SEC will generally be suspicious of ceding regulatory jurisdiction to the Federal Reserve.

These domestic challenges are compounded in the international sphere. Domestic bank holding companies generally insist that any increase in capital, liquidity, or maturity requirements above the international floor set by Basel will disadvantage them vis a vis their foreign competitors. The likelihood that these increases could be accomplished solely through the Basel process is dim. There are too many countries with predominantly bank-based financial systems where the contemplated increases would substantially impede the provision of credit. The possibility of capital market substitution is what provides U.S. regulation with unique opportunities. At least some international coordination would be required for enforcement. Extending banking regulation to nonbank competitors like securitization vehicles or investment trusts would create pressure for some of that activity to locate abroad. This arbitrage would take place in the countries

218. I thank Dan Farber for bringing this point to my attention.

219. John C. Coffee, Jr., The Political Economy of Dodd-Frank: Why Financial Reform Tends to be Frustrated \& Systemic Risk Perpetuated, 97 CORNELL L. REV. 1020 (2012); Adam J. Levitin, The Politics of Financial Regulation and the Regulation of Financial Politics, 127 HARV. L. REv. 1991 (2014). For an opposing view emphasizing the iron-clad limits of post-crisis regulation, see Roberta Romano, Regulating in the Dark and a Postscript Assessment of the Iron Law of Financial Regulation, 43 HOFSTRA L. REV. 25 (2014).

220. Jesse Hamilton, Fed Working on Proposal to Ease Up on Bank Leverage Limits, BLOOMBERG POL. (Jan. 19, 2018, 4:00 AM), http:/www.bloomberg.com/news/articles/2018-01-19/fedsaid-to-be-finishing-proposal-to-ease-up-on-bank-leverage [http://perma.cc/5B2Z-96ER].

221. John Heltman, FSOC Gives Up Effort to Designate MetLife as SIFI, AM. BANKER (Jan. 18, 2018, 9:45 PM), http:/www.americanbanker.com/news/fsoc-gives-up-effort-to-designatemetlife-as-sifi [http://perma.cc/Z8RE-8PCD].

222. Id. 
with capital market activity that was deep enough to absorb these financial flows, and domestic regulation would not have the power to prevent it.

There is still a case to be made that, at least in principle, the United States could go it alone. The restrictions that were placed on banks in the aftermath of the Great Depression likely facilitated, rather than restricted, the development of U.S. capital markets. They provided benefits in the form of a protected market for deposits and price controls, but they also prohibited commercial banks from participating in investment banking. The model of regulation described here would help the safety and profitability of the banking sector, but it would also limit its size and encourage the institutional development of market-based substitutes that could more readily absorb risk without triggering panic.

I have thus far described largely technical and institutional obstacles that would prevent the implementation of this model. Another possibility is that, once passed through the filter of politics, its implemention would have largely pernicious consequences. Banks could shape the regulatory process so to prevent the entry and expansion of nonbank competitors. They could eventually neuter the implementation of any heightened prudential standards and grow both proportionally larger and panic prone over time. Implicit subsidies provided as a byproduct of an effective regulatory tax could be turned explicit, reinforcing the idea that large banks are too big to fail. This could set banks on a path similar to the GSEs, as government subsidies come to support ever riskier lending practices over time. ${ }^{223}$ Alternatively or additionally, nonbanks could be the beneficiaries of failures to prevent the large-scale migration of banking activity outside of bank holding companies. A shadow-banking sector of highly-levered and maturity-mismatched financial intermediaries could emerge that serves as ground zero, again, for a future crisis.

All this is to say that there is no model of regulation, existing or untried, that cannot be rendered completely ineffective or turned into a corrupt caricature of itself in the right political circumstances. Still, any given model can be described as more or less consistent with an expected legal, political, and economic equilibrium. In a polity with consistent left to right swings of some amplitude, more aggressive regulatory measures in one political cycle can prove destabilizing if undone with little forethought in the next. This is the lesson of aggressive deregulation followed by crisis. The model described here could, however, appeal to different political constituencies and therefore temper these swings. It features a much more aggressive approach to regulating banks, but does so with the intent of replacing banks with less risky forms of intermediation through the financial markets. As described, if the model were to be adopted and then abandoned, assuming the political cycles that have marked banking

223. For an explanation of the financial crisis that emphasizes the role of the GSEs, see Peter J. Wallison, Hidden in Plain Sight: What Really CaUsed the World's Worst Financlal CRISIS AND WHY IT COULD HAPPEN AGAIN (2016). 
regulation over the last several decades, it would mean no worse than reverting to the status quo. The political dynamics of the present, however, provide no such guarantees.

\section{Conclusion}

This Article has attempted to reinterpret and reassess key aspects of the history of bank regulation from standpoint of the present. It starts with what are broadly recognized as two of major weaknesses of prudential bank regulation in its current form: risk monitoring and regulatory arbitrage. Understanding past regulatory practices is useful if it can inform these two contemporary issues. The restrictions on price, product, entry, and location that were features of New Deal bank regulation had well understood costs, but in hindsight we can better appreciate some of their benefits. Ironically, these benefits are best understood by viewing regulation through the lens of public choice theory.

Public choice theory, in its strongest form, views regulation through the lens of industry rent seeking. The entire legal, political, economic structure of regulation can be explained as means of helping an industry to solve its cartel or oligopoly coordination problem. In the case of natural monopolies, a close fit between public choice theory and empirical practice may be damning. However, the case of banking may be different. In banking, competitive restrictions created rents that curbed bank incentives for risk taking and enlisted banks in limiting the issuance of deposit-like claims outside the regulatory banking sector.

I outline one of many possible models of prudential regulation that relies on this insight. This model would subject bank holding companies to stringent enough capital, liquidity, and maturity requirements to lower the aggregate yield on short term bank debt. It would subject nonbanks to even more aggressive requirements on each of these dimensions and utilize banks in the enforcement of this limitation on would-be competitors.

In general, it is often the task of regulation to limit the quantity of an externality-producing good in an environment where regulators face a number of monitoring and enforcement constraints. In such environments, it may be useful to create a legal privilege through which the price benefits of the quantity limitation redound to a set of privileged institutions. Such a rent would normally give those so privileged, as well as their unlucky competitors, an economic incentive to expand output. Expanding output, however, undermines the effectiveness of regulation. This tendency can be balanced through a legal and political architecture that enables the privileged to collectively prevent such an expansion from occurring. 
